University of Louisville

ThinkIR: The University of Louisville's Institutional Repository

Electronic Theses and Dissertations

$12-2012$

\title{
Finding the brutal aesthetic.
}

Marcy R. Werner

University of Louisville

Follow this and additional works at: https://ir.library.louisville.edu/etd

\section{Recommended Citation}

Werner, Marcy R., "Finding the brutal aesthetic." (2012). Electronic Theses and Dissertations. Paper 1549. https://doi.org/10.18297/etd/1549

This Master's Thesis is brought to you for free and open access by ThinkIR: The University of Louisville's Institutional Repository. It has been accepted for inclusion in Electronic Theses and Dissertations by an authorized administrator of ThinkIR: The University of Louisville's Institutional Repository. This title appears here courtesy of the author, who has retained all other copyrights. For more information, please contact thinkir@louisville.edu. 


\title{
FINDING THE BRUTAL AESTHETIC
}

\author{
By:
}

\author{
Marcy R. Werner \\ B.A. University of Kentucky, 1992
}

\begin{abstract}
A Thesis
Submitted to the Faculty of the

College of Arts and Sciences of the University of Louisville in Partial Fulfillment of the Requirements

for the Degree of
\end{abstract}

Master of Arts

Department of Fine Arts

University of Louisville

Louisville, KY

December 2012 
FINDING THE BRUTAL AESTHETIC

By

Marcy R. Werner

B.A., University of Kentucky, 1992

A Thesis Approved on

November 26, 2012

By the following Thesis Committee:

John P. Begley

Thesis Director

Elizabeth Reilly

Mary Carothers 


\section{ACKNOWLEDGMENTS}

I want to thank the people that made this project possible. Andrew Ranard, John's brother, aided my research, providing rare articles and quick answers, all from his home in Japan. Bill Carner, a close friend of John Ranard who, through his stories, gave insight into John's personality, background, and methods. He taught me how to look at Ranard's photographs and coached me on how to 'do an artist justice', talking me down from a desire to show over 50 photographs. We settled for 28 and he made me feel okay about that. Thanks to Casey Harden and the Muhammad Ali Center. This exhibition opportunity came quickly and her efforts made it a smooth experience. The Photographic Archives at the University of Louisville allowed me uncontrolled access to Bill Carner and loaned one of the most favored photographs in the exhibit. Thanks to Amy Fordham at the Visual Resource Center for giving me an incredible work space. Most of all I would like to thank John Begley. He introduced our class to the work of John Ranard. I had forgotten how much I loved working with photographs and it set me on the rediscovery of a long-lost path. I have worked with these photographs in some capacity every semester since and he has encouraged and guided each step. 


\title{
ABSTRACT \\ DISCOVERING THE BRUTAL AESTHETIC
}

\author{
Marcy R. Werner
}

November 26, 2012

This thesis project documents the curatorial and archival work completed using the collection of photographs, negatives, and ephemeral materials of John Ranard. This collection belongs to his estate and is currently housed at the University of Louisville. Mounting an exhibit, processing the collection, and constructing a finding aid were parts of this project. Approaching the materials with a curatorial mindset informed the arrangement of the collection, one that compliments potential future curatorial endeavors with the collection. 
TABLE OF CONTENTS

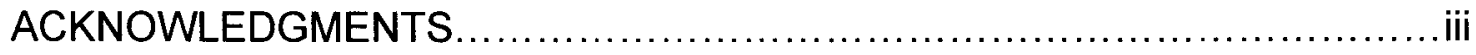

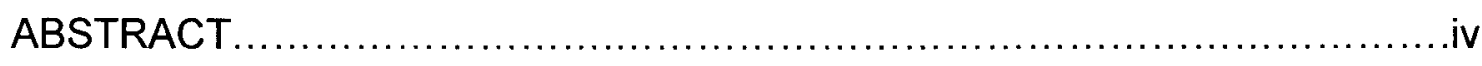

LIST OF PHOTOGRAPHS ....................................................

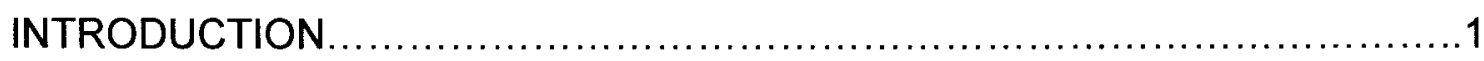

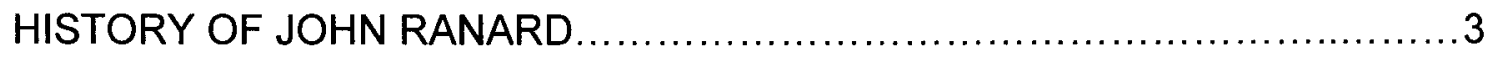

CREATING THE BRUTAL AESTHETIC EXHIBIT ..............................

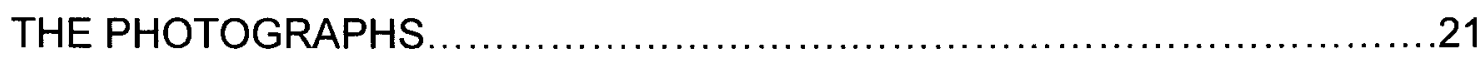

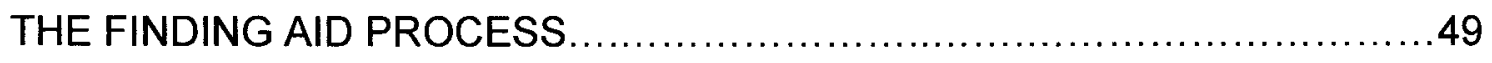

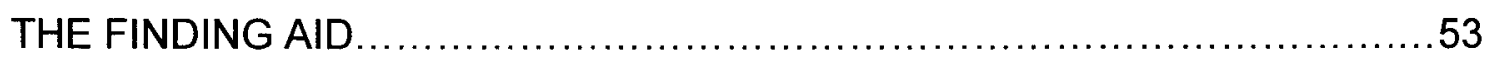

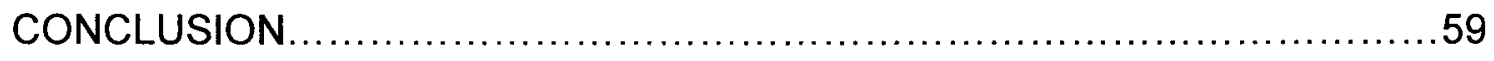

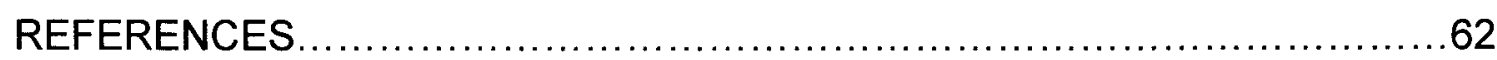

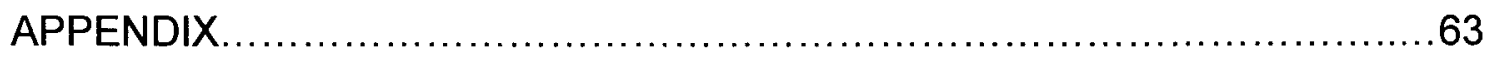

1. EXHIBITION WALL TEXT ........................................63

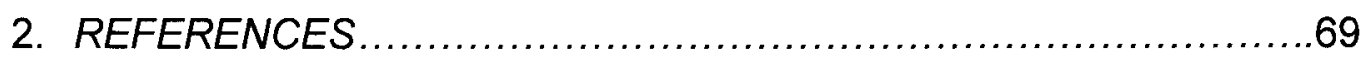

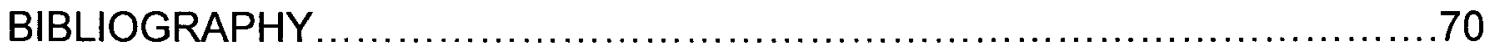

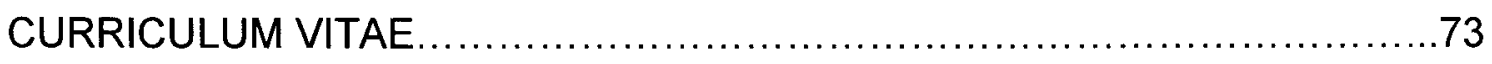




\section{LIST OF PHOTOGRAPHS}

1. Jimmy Ellis and John Ranard, Digital ink-jet print. Photographer unknown.

2. Baxter Two Gym, Amateur Boxing, Louisville, KY (1979), Gelatin silver print.

3. Eddie Davis, Las Vegas, NV (1982), Gelatin silver print.

4. Round One-Jerry Mclntyre (vs. Greg Page), Louisville, KY (1979), Gelatin silver print.

5. Road Trip, Baxter Two Boxing Team, Louisville, KY (1979), Gelatin silver print.

6. Card Girl, Las Vegas, NV (1980), Gelatin silver print.

7. Card Girl-Round 3, Bloomington, MN (1980), Gelatin silver print.

8. Mike "Iron" Tyson, Madison Square Garden, New York, NY (1988), Gelatin silver print.

9. Purcell Davis Weighs In, Bloomington, MN (1979), Gelatin silver print.

10. Bed-Stuy Boxing Club, New York, NY (1986), Digital ink-jet print.

11. Nick Kendrick, Kentucky Golden Gloves, Louisville, KY (1980), Gelatin silver print.

12. Johnny Bumphus, Atlantic City, NJ, Gelatin silver print (1986).

13. Andrews vs. Leach, Atlantic City, Atlantic City, NJ (1986), Gelatin silver print.

14. Scott LeDoux vs. Ken Norton, Bloomington, MN, (1979).

15. Mills Lane, Holmes vs. Cooney Bout, Las Vegas, NV (1982), Gelatin silver print.

16. Victor Rodriguez (vs. Greg Page), Louisville, KY (1980), Gelatin silver print.

17. Baker Tinsley, Louisville, KY (1979), Gelatin silver print. 
18. Cooney Security, Las Vegas, NV (1982), Gelatin silver print.

19. Renaldo Snipes vs. Bobby Crabtree, Felt Forum, New York, NY (1988), Digital ink-jet print.

20. Willford Scypion (vs. Iran Barkley), Felt Forum, NY (1988), Digital ink-jet print.

21. Ken Norton, Bloomington, MN (1979), Gelatin silver print.

22. Tillman vs. Cooper, Atlantic City, NJ (1988), Digital ink-jet print.

23. Ken Norton, Bloomington, MN (1979), Gelatin silver print.

24. Greg Page vs. Don Martin, Louisville, KY (1979), Gelatin silver print.

25. Greg Page's First Prizefight, Louisville, KY (1979), Gelatin silver print.

26. Greg Page at Baxter Gym, Louisville, KY (1977), Gelatin silver print.

27. Greg Page, Louisville, KY (1979), Gelatin silver print.

28. Greg Page vs. Trevor Berbick, Undercard Bout, (1982), Gelatin silver print. 


\section{INTRODUCTION}

In the summer of 2010 I enrolled in two classes at the Campbell Center, an institution specializing in continuing museum education with a focus on preservation and conservation. These classes were on the identification of process, preservation, and conservation of photographs from daguerreotypes to gelatin silver prints. Taught by Gary Albright, head of conservation at the Eastman House, the classes allowed for hands-on conservation exercises under the tutelage of a professional. These classes acted as an extension of the education I received as an intern with the University of Louisville's Photographic Archives. There I had researched and digitized a small collection of glass negatives and photographs while learning of proper handling and storage practices. Both of these experiences lead me to create an independent study class where I assessed the condition of the photographs of John Ranard. A small part of his collection is being stored at the University, retrieved from a storage facility in New York where they had been since Ranard's death. These photographs were brought to the University in 2009 to create a retrospective exhibit of Ranard's work after his death in 2008.

With such a recent showing of Ranard's work, it did not occur to me to use these photographs for my thesis project. However, about a year later I received a call from the Muhammad Ali Center with a request to curate an exhibit of 
Ranard's boxing photographs. Peter Morrin, a member of the Board of Directors and a professor at the University, facilitated this introduction and idea. He had knowledge of the collection and offered the suggestion to the Center. Two short months later, The Brutal Aesthetic opened in a gallery of the Muhammad Ali Center.

Because of the small window of time for curating The Brutal Aesthetic, the biggest challenge I faced was with the organization of Ranard's collection. The boxes were labeled, but most with multiple labels. Organization within the boxes was true to theme but not to the notes written on the boxes. A box labeled 'Boxing, signed' would contain more than boxing photos; postcards, contact sheets, and negatives, and photographs that were signed and unsigned would be found in the box. The Ranard collection is rich with potential themes and ideas for future exhibitions. It was at this point I knew the project needed to continue with an organization of the materials to ensure ease of use.

After the exhibit was dismantled I began to process the collection and create a finding aid. This part of the project coincided with a class on the methods, ethics, and best practices of processing collections. Processing the collection consisted of the arrangement, description, and rehousing of the photographs in archival quality storage for future research and use. 


\section{CHAPTER I}

\section{HISTORY OF JOHN RANARD}

John Ranard, a social documentary photographer, passed away in 2008 at the age of 56 , only thirty years into a prolific photographic career. As the son of a Foreign Service Officer, his formative years were spent living abroad in Malaysia, Korea, Burma, and Australia. Through this upbringing he became comfortable inserting himself into unknown places and among a variety of people. He was intrigued by the subcultures of these places, finding their interests and lifestyles compelling. These people became his subjects. He found his work in documenting their lives and activities.

Ranard returned with his family to the States as a teenager, living in Virginia and finishing high school. He attended college in New Mexico, studying Russian history and photography, and then returned to Virginia. A few years later he broke his neck in a car accident. After a long recovery, Ranard used his settlement money to attend the now-defunct Center for Photographic Studies in Louisville, Kentucky in the late 1970's. It was here that his skills as a social photographer began to take shape. He worked for a few of Louisville's alternative publications and developed his series, "Ranard's Picture Show", which he would later continue in New York's The Villager. 
While in Louisville, Ranard began photographing various sporting events in the region and around the country. Kentucky Derbys, rodeos, and fishing competitions were among many events that caught his interest. However, it was the serendipitous location of his apartment that lead him to one of his more famous bodies of work. Across the street from his place in the Highlands neighborhood of Louisville was a boxing gym. Curious of all the activities taking place in and around the building, he investigated (Carner). A few years later he emerged with a self-assembled book of boxing photographs and a close friendship with one-time heavyweight champion, Greg Page. He unsuccessfully sought to publish the book titled The Brutal Aesthetic. A later collaboration with Joyce Carol Oates, On Boxing, would use many of the same photographs.

After following these sporting events around the country for several years, Ranard settled in New York. From the mid 1980's through the early 90's, Ranard documented the turbulent times East Village, particularly the Squatter's Rights protests around Tompkins Square Park (Castrucci) as well as the flourishing alternative lifestyles of the area.

In the mid 1990's, Ranard traveled to Russia to photograph the Soviet regime as it was crumbling. In Russia he found rich subject matter and events that were escaping the attention of mainstream media. He documented the Russian prison system, at both male and female institutions, the rampant drug use, and the AIDS epidemic. His photographs of AIDS victims accompanied an essay published in the New York Times. The photographs won him first prize for Issue Reporting Story from the National Photographer's Association and helped 
secure sponsorship from the Soros Foundation Open Society to continue documenting the crisis. AIDS Foundation East/West used these photographs in media campaigns throughout Russia.

In 2005 Ranard started working for The Villager in New York. Reviving "Ranard's Picture Show", he sought out various subcultures such as freegans foraging for food in dumpsters, the rise of nouveau burlesque, and events like James Browns' funeral and the popularity of one of the oldest Mosques in New York. Ranard enjoyed the freedom to experiment and be creative while working for The Villager, which showed in the diversity of his subjects (Andrew Ranard).

While at The Villager Ranard began returning to Louisville where he started to explore the tense race relations in the city. The project quickly morphed into a photo essay on small African-American community churches on the West side of town. On Every Corner, the title of this portfolio, refers to the plethora of these churches and communities he photographed.

In 2006, Ranard's health began to suffer and he developed liver cancer. His new subject became himself. He documented his struggles with the disease and his attempt to recover from a liver transplant he received in 2007 . One of these self-portraits was the last photograph to be published by him in The Villager at the end of 2007 . He passed away 5 months later.

Ranard had a long-standing relationship with Louisville and many artists in the community. During his time at the Louisville Center for Photographic Studies he met Bill Carner who would later become an archivist with the University of Louisville's Photographic Archives. Ranard's ties to Louisville and his close and 
continuing friendship with Bill Carner prompted a memorial exhibit in Louisville soon after his death. A large portion of Ranard's work, photographs and negatives, was brought from a storage facility in New York in order to curate the exhibit at the University's Cressman Center for Visual Arts in 2009. The exhibit covered many themes Ranard had photographed over thirty years (Keish). This portion of Ranard's photographs and negatives continues to be housed at the University and is about half of his known body of work.

\section{The Boxing Photographs}

John Ranard's exploration of the boxing world began in the late 1970's through to the mid 1980's. The boxing photographs represent the most complete documentary project of his early career. Previously dated materials in the collection are of a plethora of subject matters yet they lack the depth of involvement seen in the boxing work. It is with this subject that Ranard began his journey from documentary photographer to social documentary photographer.

The documentary photographer records historical and important moments, interesting activities, or daily life. The images are candid and read as being objective. Documentary photographers are often categorized with photojournalists. Ranard's early boxing photographs fit this description. They are observances of the physicality, the sport, and the attitudes of the men participating. Later, after a few years' involvement in the sport, Ranard's images begin to shift in their meaning. They start to go beyond simply recording people in their environment and strive towards a critique of certain aspects of boxing. 
The social documentary photographer is similar to the documentary photographer in capturing moments of daily life but their goal is to create awareness of a need, often for social or political change. They often focus on the underprivileged, poor, or exploited. Ranard did not set out to critique the sport of boxing, but some of the photos can be read as critical of the nature of the business side. Some of these images were not included in the exhibit at the Ali Center but would be appropriate for another venue or a differently themed show. They focus on the promoters, managers, and backers of the sport whose wealth and position is evident through their portraits. If these were shown with the photographs of young African-American men being weighed (Figure 9), transported (Figure 5), and escorted (Figure 8), the meaning of these photographs would be read quite differently. There are several directions this body of work could be taken to imply other meanings. There are more photographs of these scenarios that would create compelling examples of the exploitation of a group of people.

Ranard wants the viewer to see this world a certain way. Like most social documentary photographers, the aim is to bring attention to a subject with the hopes of creating awareness of a need for change. I do not believe Ranard was being overtly critical of the sport but instead honing his sympathetic and critical eye for future bodies of work. At this point in his career, Ranard was evolving from documentary to social documentary photographer. The demonstration of this transition seen in this body of work makes these boxing photographs the most pivotal of his career. 


\section{CHAPTER II}

\section{CREATING THE BRUTAL AESTHETIC EXHIBIT}

John Ranard had hoped to publish The Brutal Aesthetic, a book of his photographs from several years spent following the boxing circuit. His brother Andrew has the only existing copy, a cut and paste book of photocopies of the chosen images. Digital versions of these same photographs exist on Ranard's hard drive in several differently titled folders. Peter Morrin, head of the Arts and Culture Partnership Initiative and a professor of museum studies at the University of Louisville, had knowledge of Ranard and these photographs. He suggested the Muhammad Ali Center contact me for an exhibit opportunity. Morrin knew I had been working with the collection. I was conducting an assessment of the condition of the photographs as a project for an independent study class. He knew I was in need of a thesis project and thought this partnership would be a good fit.

The Ali Center wanted me to curate an exhibit in one of their smaller galleries. They were launching a new program focusing on arts in the community of Louisville and hoped Ranard's work would be an ideal launch. I created a presentation of twenty photographs and a brief biography on Ranard. After I visited the Center to meet the staff and see the space, we agreed to move forward and begin developing ideas for the exhibit. 
The gallery space intended for the exhibit is on the fourth floor of the Center. It is a long hallway that opens up to a large room and closes back to a hallway. The space is accessible from either hallway, depending on how a visitor travels through the Center. In the large room is a wall mounted flat-screen television. The walls and the ceiling are painted black. It is an intimate space that provides a break from the several interactive displays and audio-visual exhibits of the Center. It was a perfect space and atmosphere for Ranard's photographs. The walls would easily allow up to 50 photographs. Removing the television was discussed at the initial meeting but would later prove cost prohibitive.

The preliminary photographs I showed the Ali Center were taken from one folder on Ranard's hard drive. There are several folders titled "The Brutal Aesthetic" and all contain variations. I used the photographs from a folder where I found the same images printed in the physical collection. All of these photographs were signed. I felt this was the best representation of a possible exhibit that would keep with Ranard's intentions. We discussed the goal of demonstrating Ranard's relevancy to Louisville arts and its history and presenting photographs that would illustrate this. We also discussed the need to project the mission and principles of the Center through the exhibit and in each photograph shown. This lead to a critique of the images I presented and how they worked within this scope. This was an exercise in looking at these images in a new light. I began to understand and set new criteria for additional photographs to choose. 
After it was established that the Center would like to proceed with the exhibit, I had time to sort through the collection at an item level. At the start, I referred to the contents of all The Brutal Aesthetic folders on Ranard's hard drive, looking for images that illustrated the mission and principles of the Muhammad Ail Center. Interpreting and expanding Ranard's intentions while keeping in the boundaries set by the Center were goals I developed as the curator for this exhibit. Another challenge I sought was to contemporize The Brutal Aesthetic book idea. The book was never published but many of the same photographs had appeared in Joyce Carol Oates' book, On Boxing. Her book is still in publication and widely known. Choosing additional and/or omitting photographs from Ranard's initial idea was an opportunity to maintain a sense of history and create a relationship to the present. Creating a symbiotic relationship with the Center's core principles provided parameters for these decisions.

Lacking solid written evidence of the overarching themes Ranard addressed in his book, investigation and interpretation were a challenge. I did not have access to the mock-up created by Ranard but because of the several versions on his hard drive there was a small sense of freedom for expanding on his original choices. The most coherent layout of his book idea is stored in a folder titled, "xbook", which appears as a sub-folder of "Brutal A-Tiff@72-5x7". There are 55 photographs in this folder, labeled by page number, as well as designs for a cover, cover wrap, quotes, captions, and a recent CV. This folder contained the most photographs of any and a completed layout of a book. I 
chose to see this as the master document illustrating Ranard's full intention by the images chosen here.

\section{Establishing criteria}

Six core principles define the Ali Center's mission: Confidence, conviction, dedication, giving, respect, and spirituality. These are broad principles and the relevance to each is explained on the Center's website. Understanding and being mindful of these principles while viewing Ranard's photographs provided valuable guidelines and a new purpose for them.

Taking Ranard's use of aesthetic to mean, "a particular theory or conception of beauty or art: a particular taste for or approach to what is pleasing to the sense and especially sight." (Merriam-Webster), I read his intention to be an exploration of the beautiful aspects within a brutal sport. While there are several photographs of the muscular bodies of boxers and triumphant moments in the ring, the majority of images are peripheral moments and activities of the boxing world. I focused my attention on these images in bringing the Brutal Aesthetic together. Here I found it necessary to understand the history of Ranard's introduction and subsequent involvement in boxing.

Ranard's journey into the world of boxing started when he grew curious of the activities he noticed across the street from his apartment in Louisville, Kentucky. He discovered an amateur boxing club and began forming relationships and taking photographs of many of the boxers. A few years later, in 1985, Ranard read an essay in The New York Times Magazine titled, On Boxing, 
by Joyce Carol Oates. He asked for and received a meeting with the author. Two years later, Oates published a book, an expanded volume of her writings, on the sport accompanied by Ranard's photographs. The book, On Boxing, was published in 1987 and Oates credits Ranard for the idea. Many of the photographs planned for The Brutal Aesthetic appeared in this book. I wanted the exhibit to include many unpublished photographs, not to be a reproduction of either book.

Oates said of Ranard's photographs, "They're very poetic. They're the highest kind of journalism, where it passes into art. They're very unpretentious." (Schudel). I considered Oates' words, "poetic" and "unpretentious" when looking at photographs to include in the exhibit.

With Ranard's digital and physical organization of the photographs, his involvement in the sport, Oates' words, and the Ali Center's mission statement as guides, I filtered through the photographs again and again. Mindful of bringing justice to an artist's work, the choices for the exhibit needed to remain close to Ranard's original intention. While this criterion was more difficult to establish, I continued gathering clues through the organization and labeling of his photographs and the ones he selected for printing.

There are thousands of boxing related images and negatives in the collection. I gave first consideration to the printed photographs. I assumed those that are signed, dated, and titled photographs had artist approval. After choosing the assumed approved photographs I moved to other images that would 
coalesce the exhibit. These photographs had to be well printed and free from damage or available in digital format for printing.

\section{The Photograph Choices}

There are 55 digital photographs in the "xbook" folder that I viewed as the master document. I immediately omitted five of these. They are either unidentifiable actions or they rely on knowledge of the person pictured to imply meaning. Focusing on the partnership with the Ali Center and bringing Ranard's work to a new, and possibly uninitiated audience, I felt they would not receive a favorable response. Ten of the images on Ranard's hard drive were printed as gelatin silver prints and in good condition, signed and dated. These were the first selected. There were other printed photographs that appeared in digital form but they again seemed to rely on an intimate knowledge of names and faces to be understood. While they have the quintessential and familiar traits of boxing photographs, winners in the ring, tense pre-bout concentration and rituals, they did not converge with the direction I was taking the exhibit.

This direction was continually tuned through regular meetings with the Ali Center. Casey Harden was my main contact during this time and she was conducting her own research on Ranard. She became interested in his life and accomplishments and we looked to expand his story in the exhibit. It was easy to get caught up in choosing photographs by relying on a visceral response and I kept reassessing, attempting to find one constant by which to judge them. While the Ali Center's principles provided guidance, I needed more grounding. In one 
meeting with Hardin, where I brought more photographs to show, she remarked how she could not understand where Ranard was positioned when he took one of the photographs. It was the comment that clarified the criteria I was looking for that would forefront Ranard in the exhibit. I considered Ranard first in each photograph, how he physically and mentally approached each shot. I do not mean to make it sound as though he was not a factor, but it was his skill I had neglected to consider, his ability to disappear in the midst of his subjects that made some of the most powerful images.

Considering Joyce Carol Oates' words, I included images reminiscent of famous art works. Purcell Davis (Figure 9) is of a boxer in the ring about to be weighed. His pose mimics that of Michelangelo's David yet his face is obscured as he takes off his shirt, causing the viewer to focus on the contour of his body. Figure 4, Round 1- Jerry Mclntyre (vs. Greg Page), is an image that struck me on two levels. It is of a boxer laying down in the ring, his eyes closed in pain, mouth open, and at least seven men surround him. Two of the men have their hand on him, cradling his head and touching his chest. At first it seemed an intrusive, exploitative photograph. Obviously Ranard had to push his way into the circle of men to get this shot. It is reminiscent of the behavior of the paparazzi and a gratuitous scene to capture. Spending more time with this image, I saw the framing Ranard used to highlight the boxer; his is the only face seen. That so many men surround him led me to think of his importance to them. This brought me to the second way of looking at this photograph. I was compelled to think of it as a contemporary interpretation of Raphael's The 
Deposition. There is tenderness captured in this image; it takes a moment of contemplation by the viewer to discover it. Many of Ranard's photographs require an investment of time from the viewer and it is rewarded with a deeper meaning or a richer story than what may first appear.

I chose photographs of the quiet moments Ranard captured around such a raucous sport. His focus was not on the physical strength of the man but of the moments leading up to its display. Like Harden, in many photographs I could not conceive where Ranard was standing, how he got his shot, or understand how his subjects appeared unaware of his proximity. Perhaps they were so comfortable with Ranard they paid him no mind. Either way, it is an envious skill. In some photographs I became aware of his position only by maintaining a concentrated effort of thinking about Ranard at work.

\section{Greg Page}

A fortuitous discovery was made while planning this exhibit- the importance of Greg Page to Ranard, to Louisville, and to boxing. I knew Ranard had formed a close friendship with Greg Page, a one-time heavy weight champion from Louisville, Kentucky. I found several photographs of Page in his collection. After some research I realized how important Page's story was to boxing. He passed away in 2009 from complications of a brain injury sustained during his final boxing match in 2001 . These complications were caused by a lack of immediate medical attention, which put Page in a coma for a week. He never fully recovered. This incident lead to updating Kentucky's boxing 
regulations to ensure medical staff is present during a match. It is a regulation that put Kentucky on par with Federal standards (Martin).

Page's birthday fell within the run of the exhibit, October 25th. With his ties to Louisville and his influence on boxing, there was a strong reason to create a sub-exhibit within The Brutal Aesthetic. The Ali Center saw Page's birthday as an occasion to call attention to the exhibit and bring awareness to his story and influence. With the focus of the exhibit becoming multi-faceted, I decided that the smaller hallway of the gallery would house the sub-exhibit on Greg Page. This could be read as an independent exhibit and as an extension of the main show. Visitors entering the gallery via the elevator would be introduced to the exhibit with a complete vignette; the story of Greg Page which would introduce The Brutal Aesthetic. Those entering from the larger entrance would view this part of the exhibit as a final tie of Ranard to Louisville and its boxing history.

There were several large format photographs of Page fighting in the ring and smaller, portrait-like ones. With a panel introducing Greg Page and his legacy, there was space for four photographs. The images of Page were arranged in a story line, from pre to post-fight scenarios. A portrait, a workout, an image of him in the ring, and a celebration around his first prizefight victory completed the small exhibit of Greg Page.

\section{The Gallery Space}

Measuring the gallery, I anticipated space for 28 photographs in $16 \times 20$ inch frames, labels for each, and 4 panels. I developed a layout of the exhibit's 
path with help from the Ali Center. They informed me that visitors use both hallways as access points to the gallery. The exhibit would have to read from both entrances. With the Greg Page sub-exhibit set up in the smaller of the two hallways, the longer and more widely used hallway became the main entrance to The Brutal Aesthetic.

A panel from the Ali Center started the exhibit and focused on the relationship of the The Brutal Aesthetic and John Ranard's work to the Center. I followed their panel with two of my own, an introduction to the exhibit and a brief history of John Ranard. As an illustration of the relationship Ranard had to the boxing world, the first photograph I hung was one of John Ranard with former Heavyweight Champion and Louisvillian, Jimmy Ellis. The photographer is unknown. It is likely Ranard handed his own camera off to a stranger at the bequest of Ellis (Carner). This is Ranard at the time he was taking these photographs; he has the reluctant smile of someone more comfortable behind the camera than in front of it. I felt this photograph was a necessary visual; a compliment to and an illustration of the panels preceding it.

Down the length of the hallway and into the larger gallery room, I concentrated on interspersing action photographs in with the quiet or humorous ones. I had also expanded the object labels for five of the photographs and took care to space them out. Every five to six photographs I would position one of these. Figure 6 and 7 are small photographs and I chose to matte them within the same frame. Showing two card girls, the label gave a brief history of their purpose in boxing matches. The next extended object label was about Mills 
Lane (Figure 15), a famous and respected referee. Other extended object labels included one on the famous Bed-Stuy Boxing Club of New York and a definition of a classical art term, Contrapposto (Figure 9). Ranard had captured a boxer in half undress mimicking this exact pose, his face obscured by his shirt. The viewer notices the relaxed attitude of the boxer through his stance and the line of his body. It is an image owned by the University of Louisville's Photographic Archives and was loaned to the Center for the exhibit. Even viewers unaware of the contrapposto concept are drawn to this image. I took the opportunity to show Ranard's knowledge of art, his readiness with the camera, and skill at shooting with film.

Originally I wanted to have over 50 photographs in this exhibit. I felt that was the best way to honor the intentions of Ranard. Bill Carner, Photo Wrangler at the University's Photographic Archives balked at that number. When I explained my reasoning he assured me I could do Ranard justice without including every intended photograph. As I was cutting down my choices of photographs to print and matte it became apparent that the television mounted in the gallery at the Center was not able to come off the wall. I decided to create a presentation of additional photographs on the television. This satisfied my desire to include more of the unpublished photographs by Ranard. These fit the mission of the Center and illustrated the depth of Ranard's interest and involvement in the boxing world.

The size of the open room of the gallery begged for objects and so did I. The photographs lead the viewer around the borders of the room but nothing led 
them to the center. Perhaps this is an unnecessary requirement but my background in visual merchandising and showroom design would not let me leave it empty. I asked for objects and pedestals and locking cases. I was loaned an out-of-print book of Ranard's by the University's Photographic Archives library and Andrew Ranard gave me a first edition of On Boxing. Murphy's Camera, a photographic supply store loaned me a Leica M3 camera, Ranard's camera of choice. The Ali Center brought the camera in under their insurance policy for the length of the exhibit.

I borrowed two pedestals from the University, one of which was internally lit, projecting light up through the top. On both of these I laid large but shallow plexiglass boxes. The Ali Center helped me rig the cases to lock and I affixed them to the pedestals with a strong adhesive. One pedestal and box contained the books of Ranard with object labels and a short explanation of their importance. With the other pedestal I used the light feature to illuminate a sheet of Ranard's black and white negatives. I cut a frame so the light would only come through the negative sheet. I placed the camera and its object label in this box as well as a contact sheet of the negatives. Showing Ranard's camera and the images he made from it was a bigger attraction than I thought. Many people remarked how long it had been since they had seen an actual negative.

When the photographs were hung and the pedestals in place, I nailed the object labels to the wall and focused the lights. Because of my partnership with the Ali Center, exhibit promotion had to be in their control. I offered to write a press release but they are required to keep that in house. They do not use 
printed flyers or announcements; instead they use electronic notices. I was able to get the announcement a week before the exhibit opened. They also had to be in charge of printing the panels but I was allowed to create the object labels myself. Having access to matte cutting equipment, Bill Carner and his printer, and a key to a supply room full of pedestals helped in the execution of this exhibit. Having just over two months to conceptualize, design, and mount the exhibit, it went smoothly. 


\section{CHAPTER IV}

THE BOXING PHOTOGRAPHS

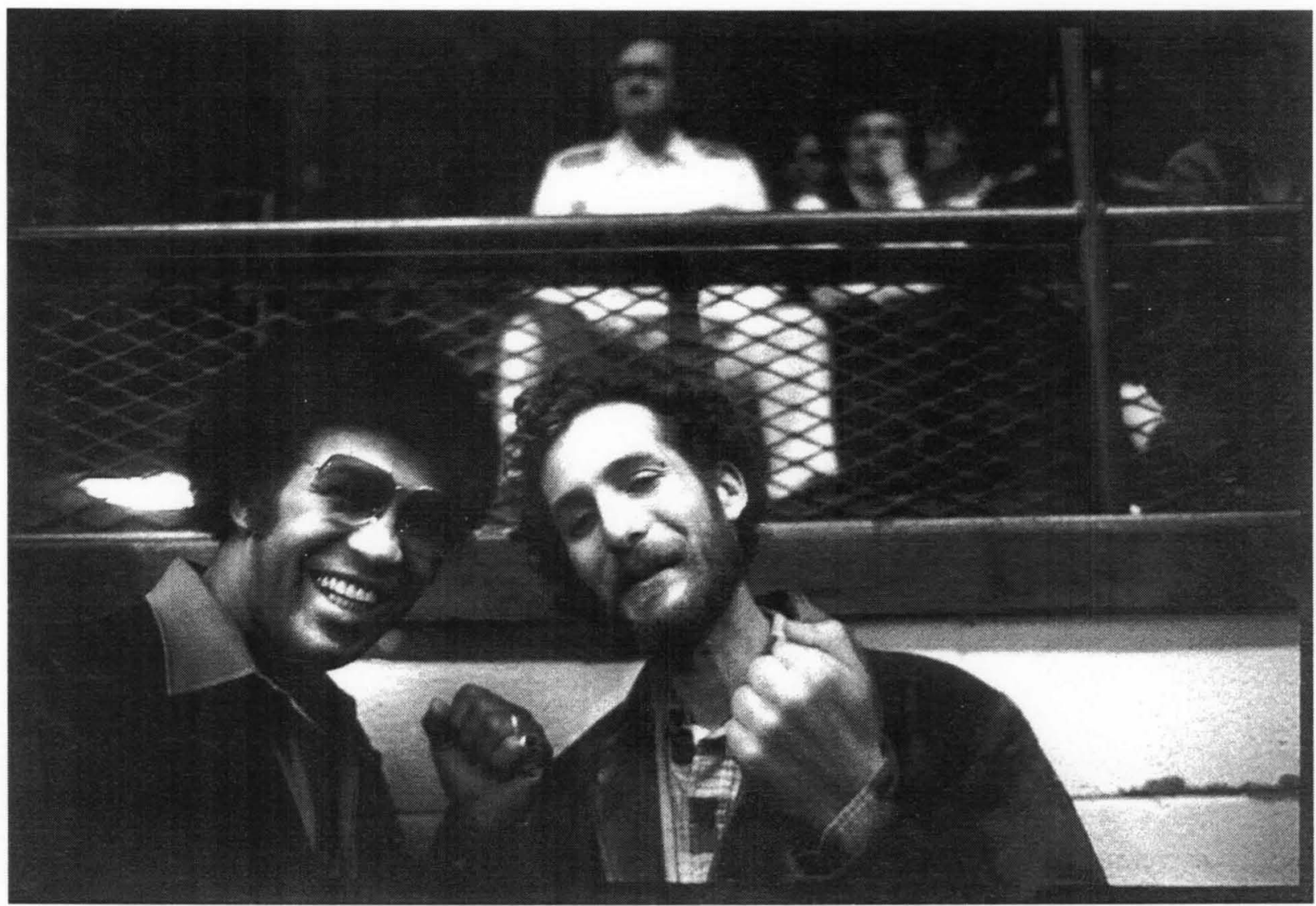

Figure 1

Photographer unknown

Jimmy Ellis and John Ranard

Digital ink-jet print 


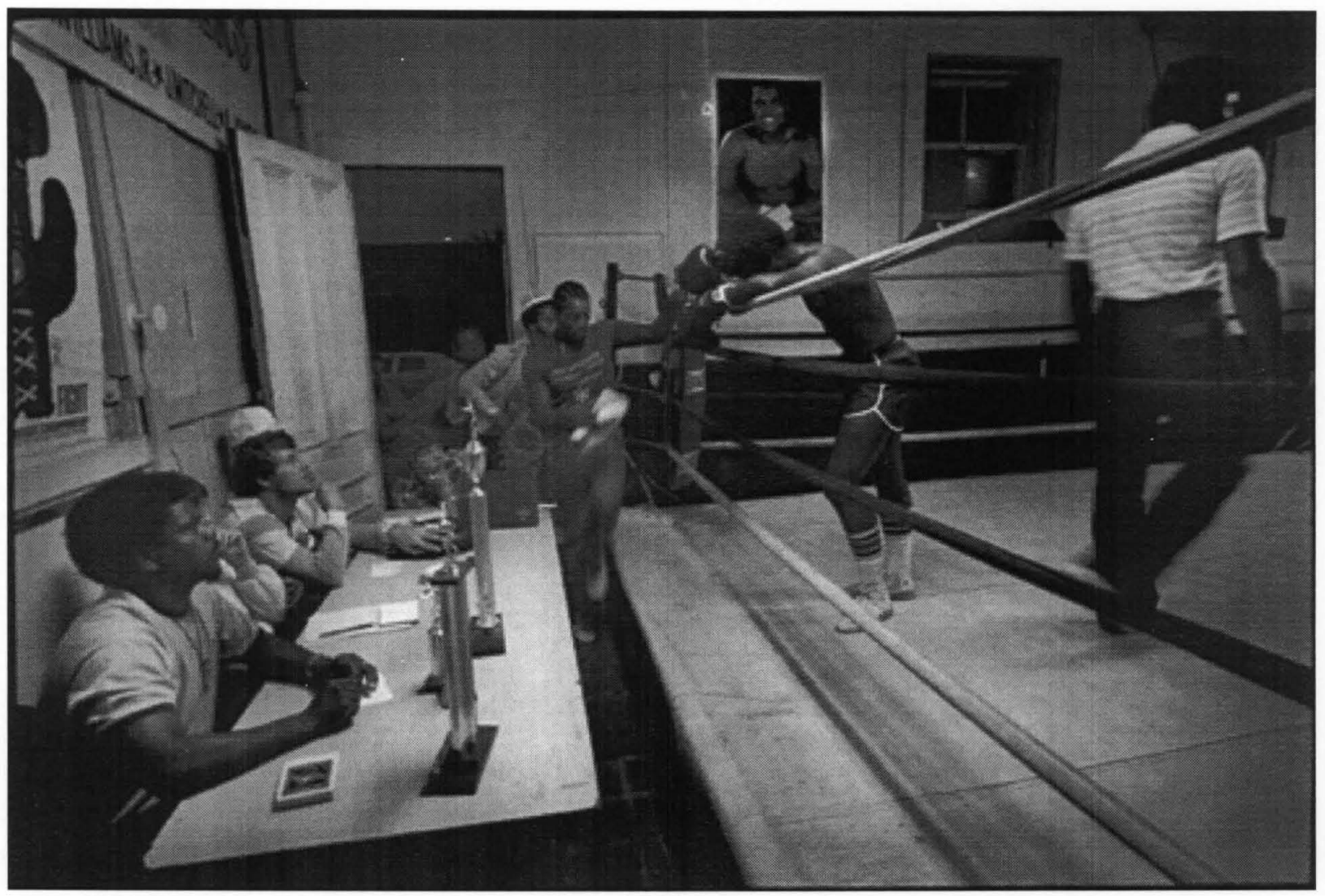

Figure 2

Baxter Two Gym, Amateur Boxing, 1979

Gelatin silver print 


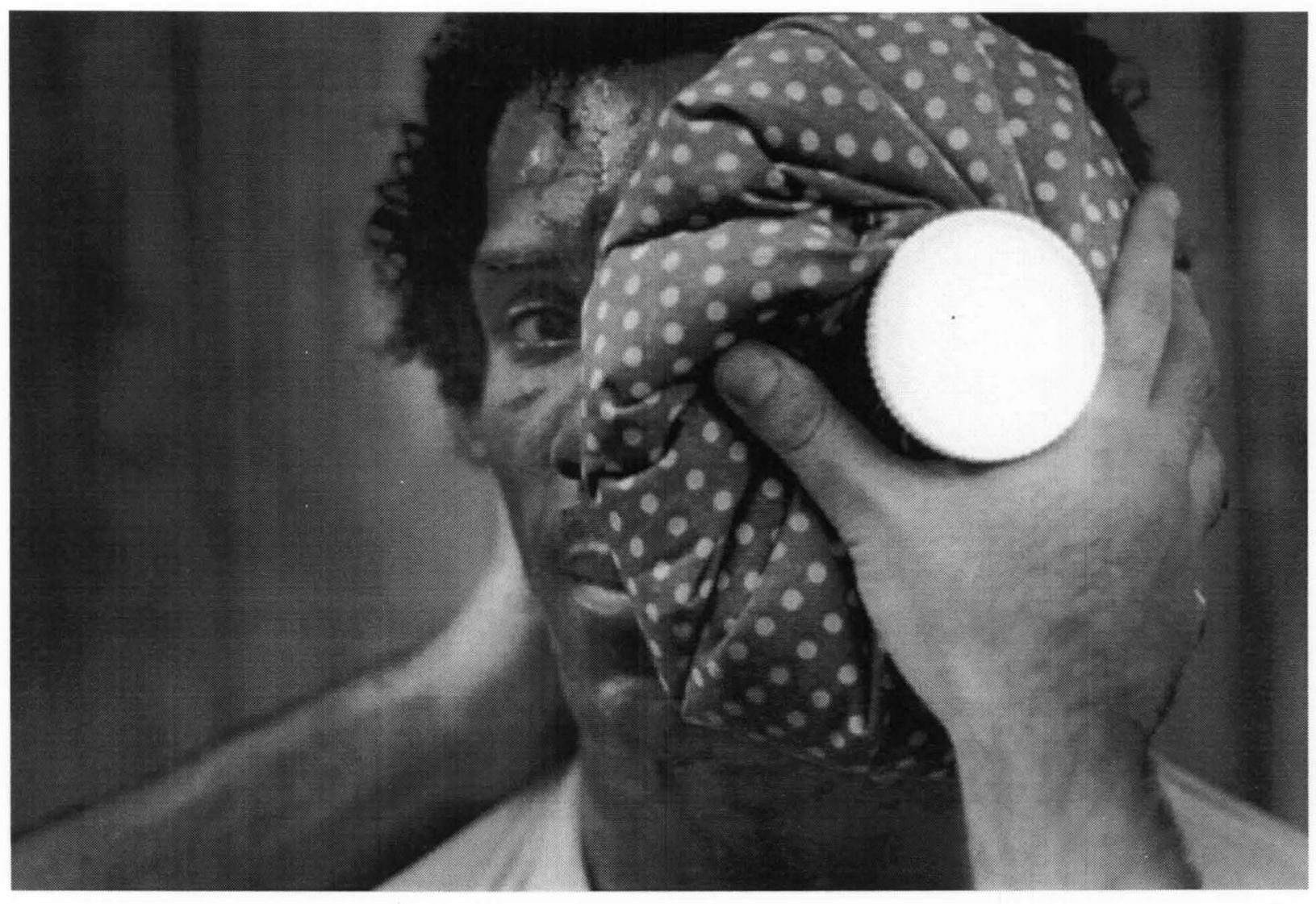

Figure 3

Eddie Davis, 1982

Gelatin silver print 


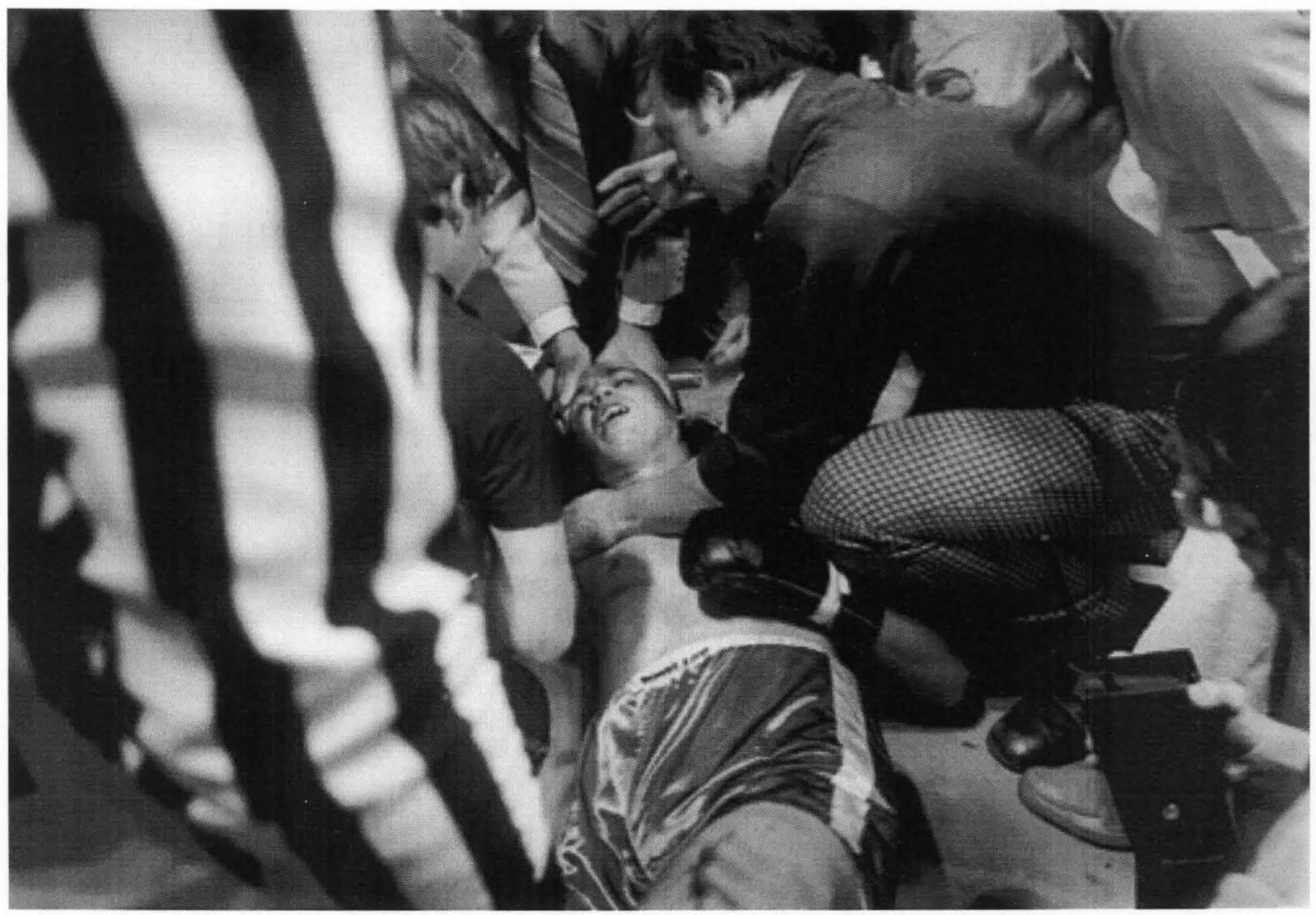

Figure 4

Round 1 - Jerry Mclntyre (vs. Greg Page), 1979

Gelatin silver print 


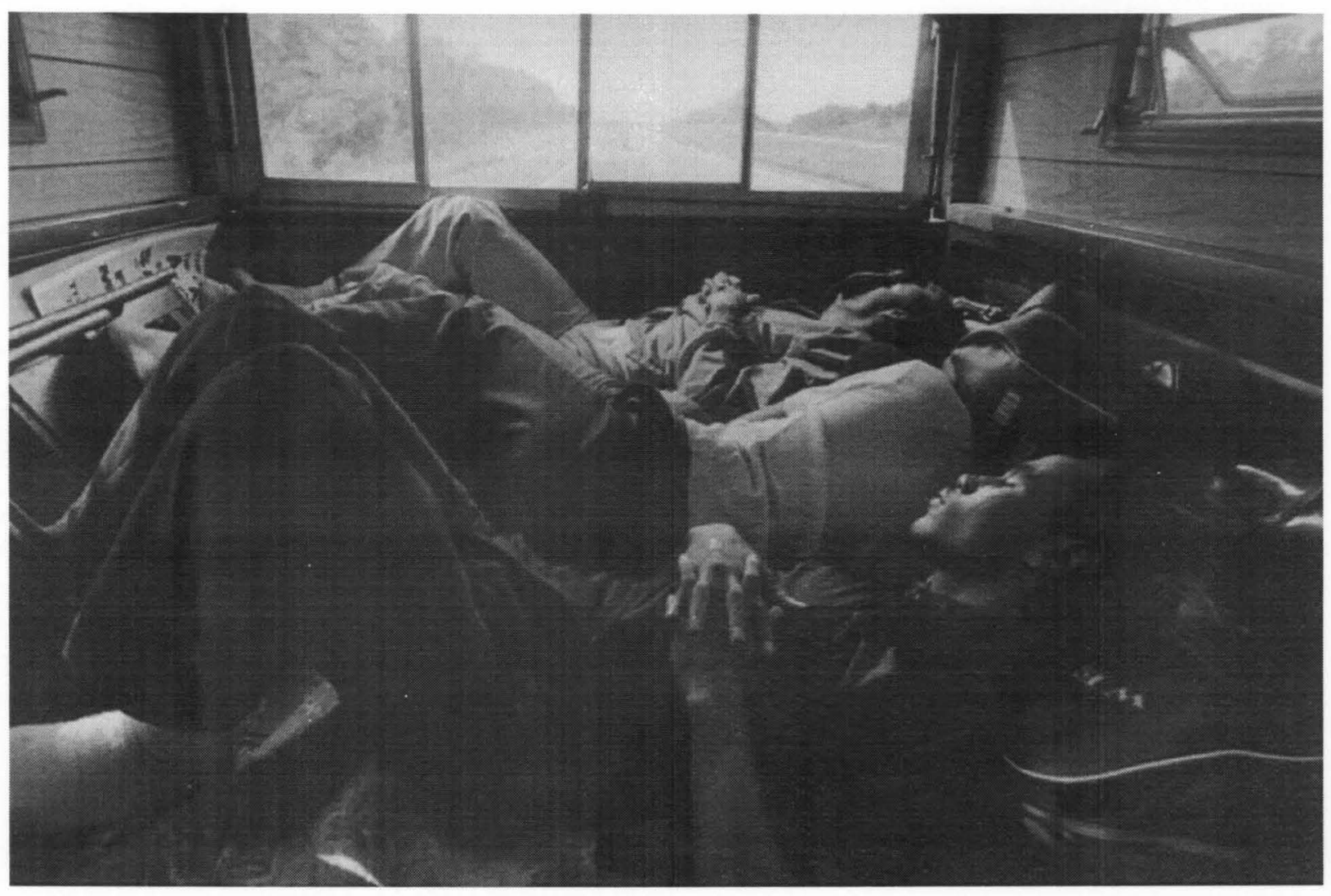

Figure 5

Road Trip, Baxter Two Boxing Team, 1979

Gelatin silver print 


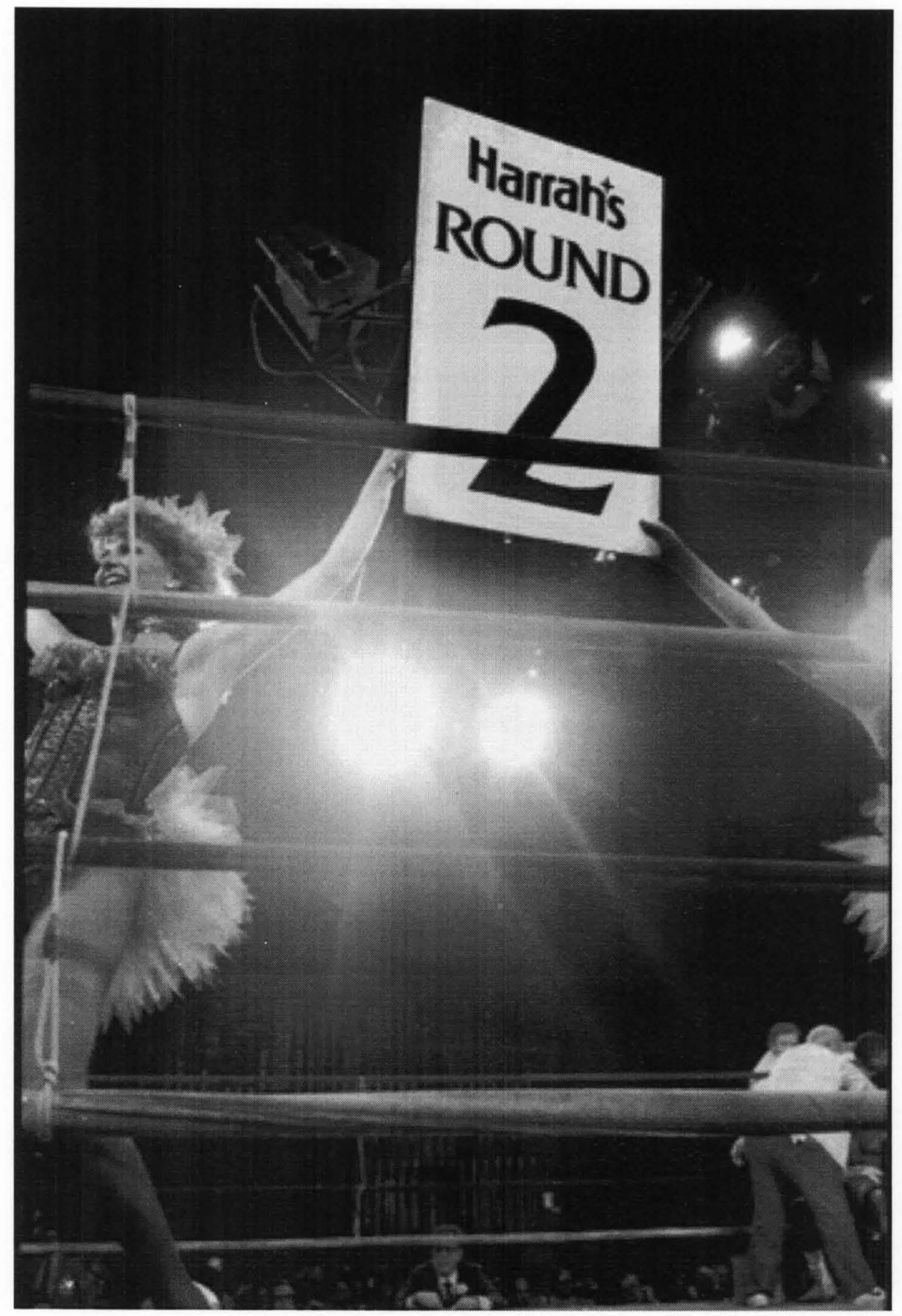

Figure 6

Card Girl, 1980

Gelatin silver print 


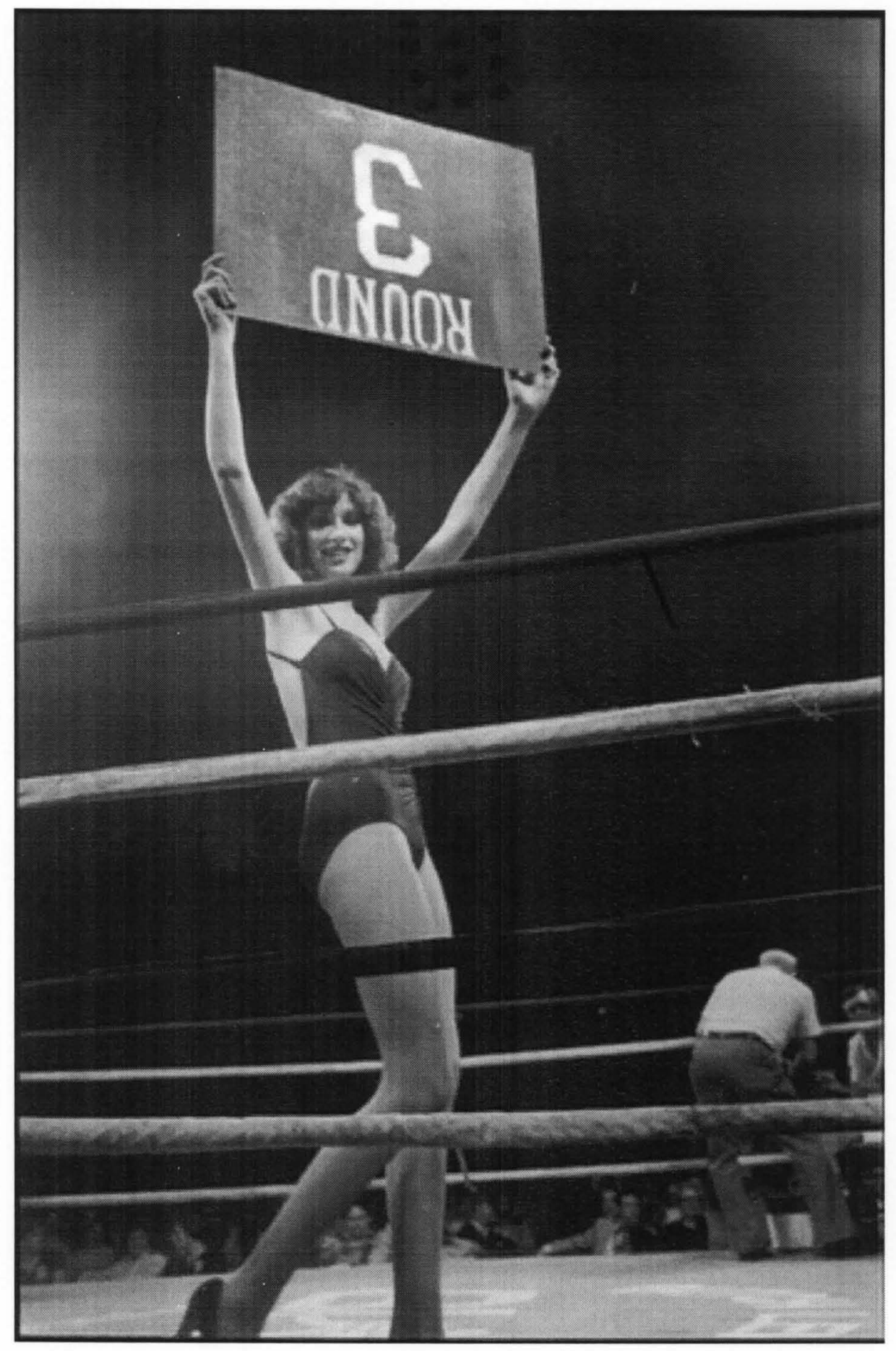

Figure 7

Card Girl, 1980

Gelatin silver print 


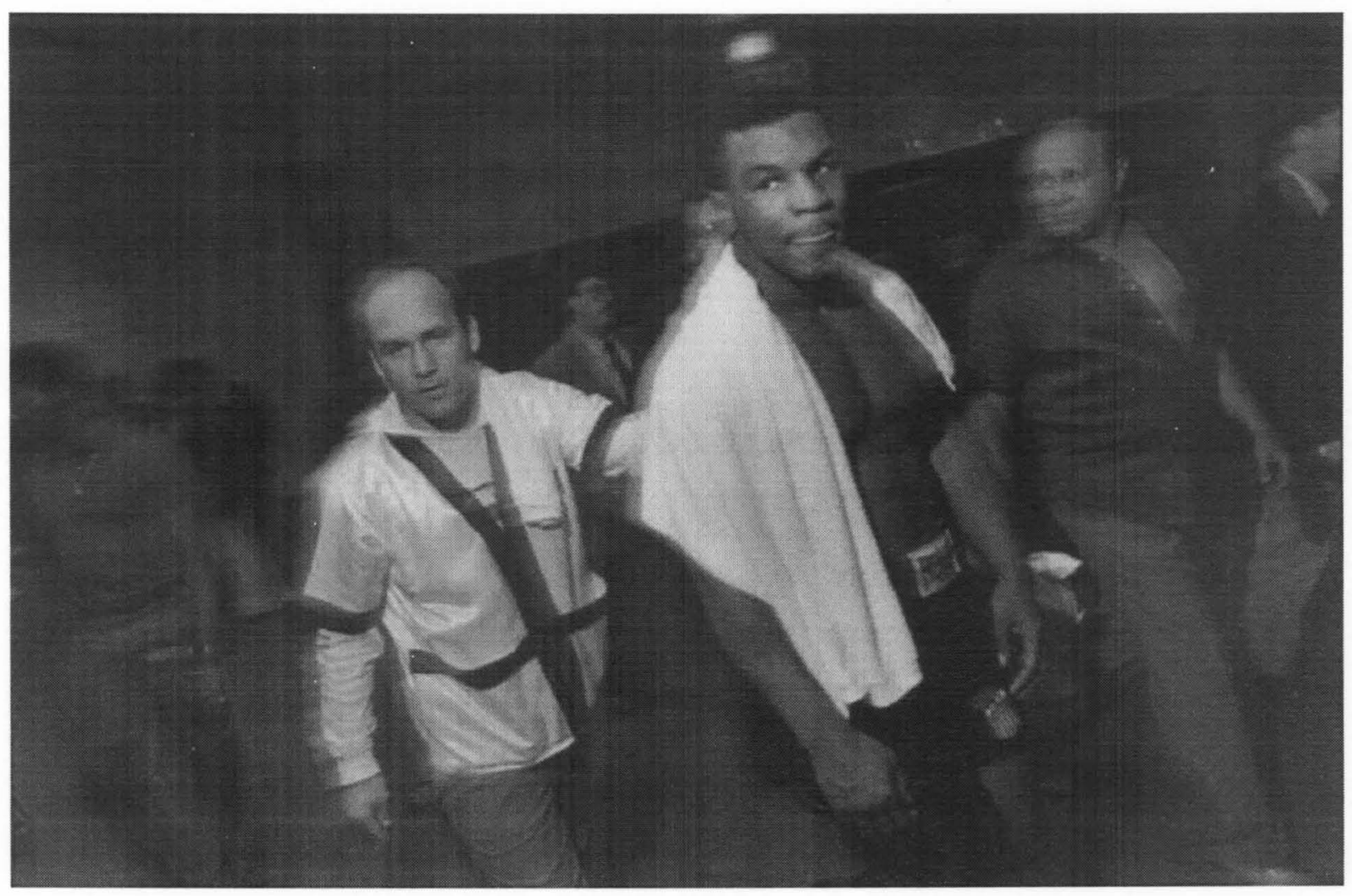

Figure 8

Mike "Iron" Tyson, Madison Square Garden, 1988

Gelatin silver print 


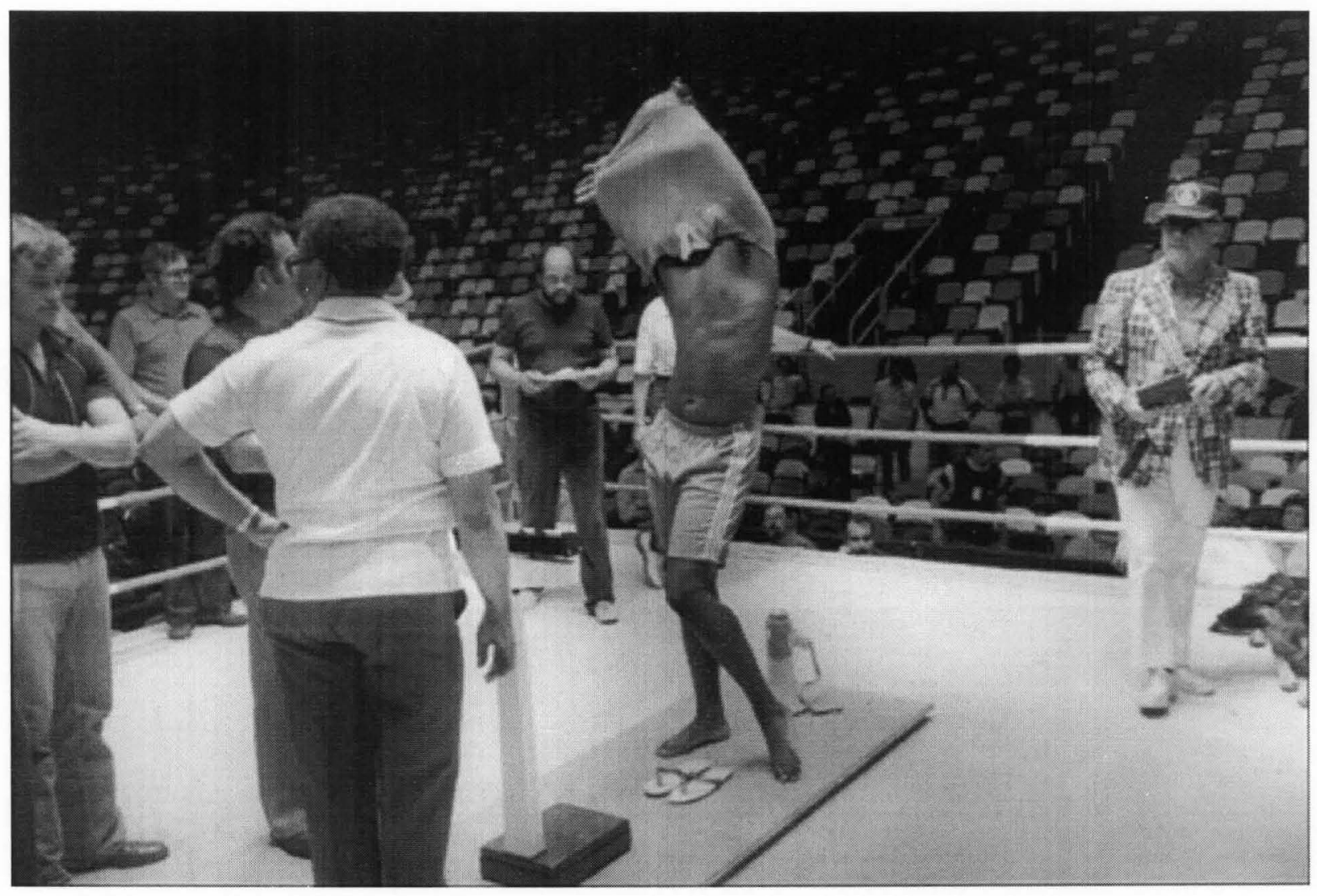

Figure 9

Purcell Davis, 1979

Gelatin silver print 


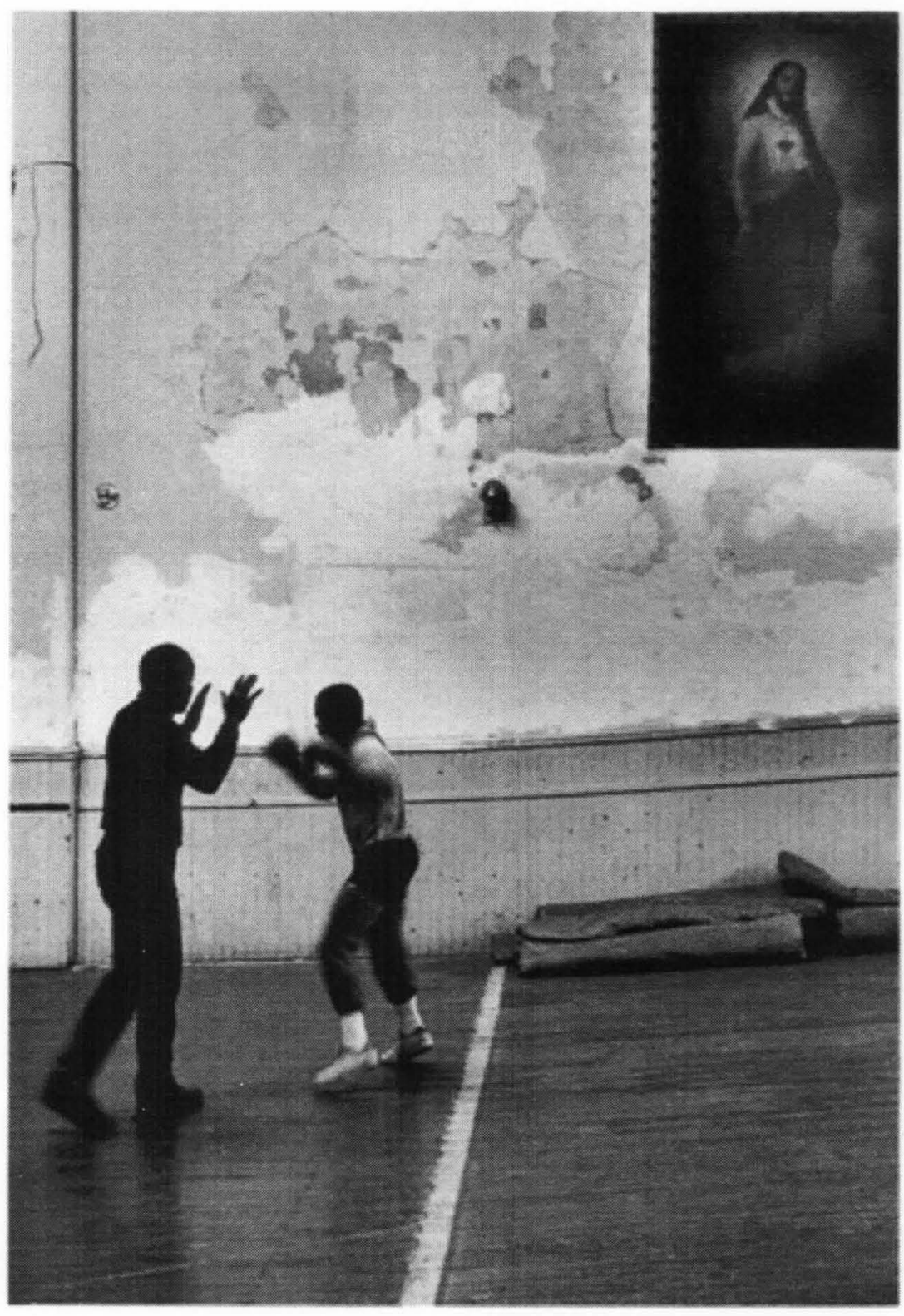

Figure 10

The Bed-Stuy Boxing Club, 1986

Digital ink-jet print 


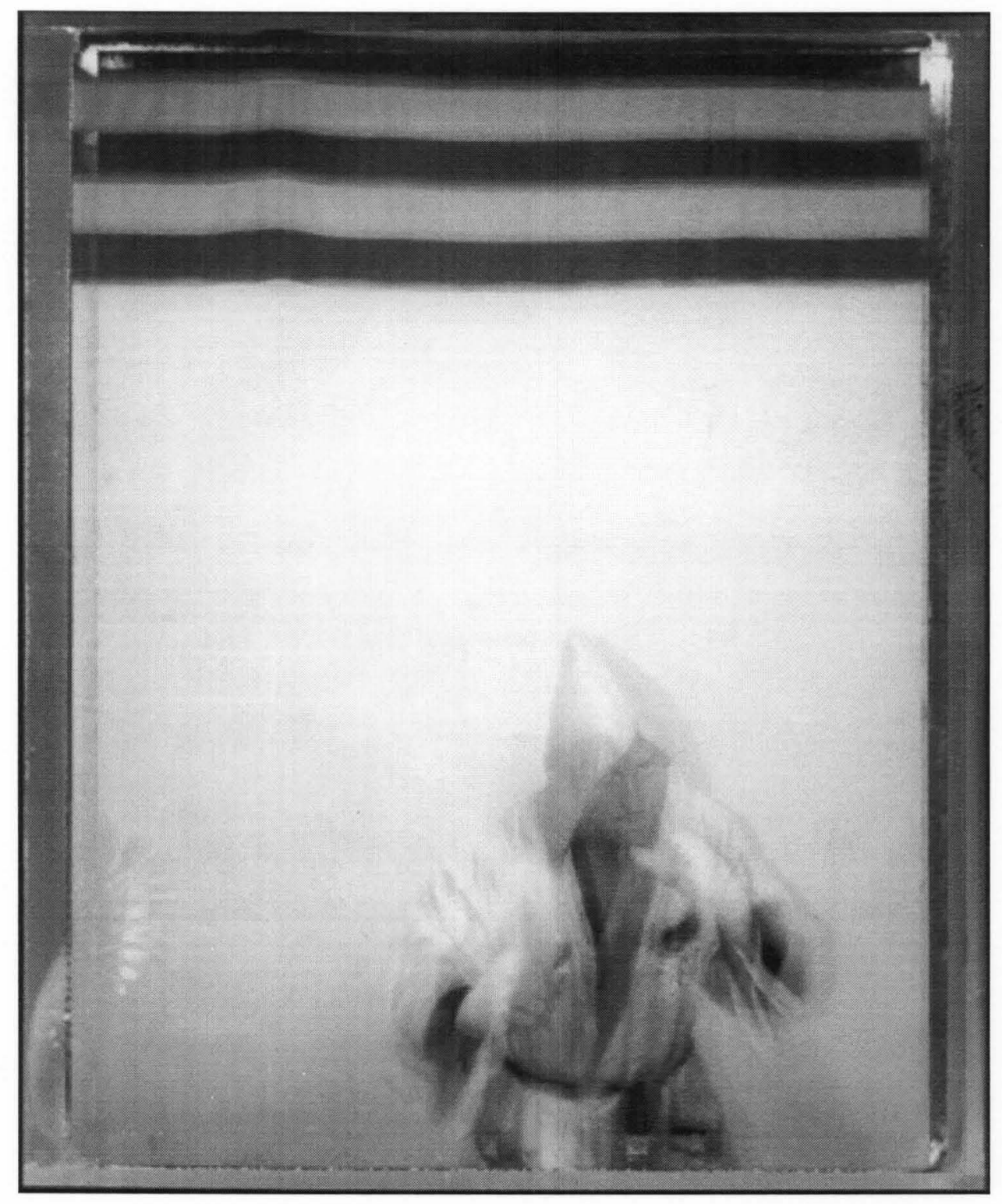

Figure 11

Nick Kendrick, Kentucky Golden Gloves, 1980

Gelatin silver print 


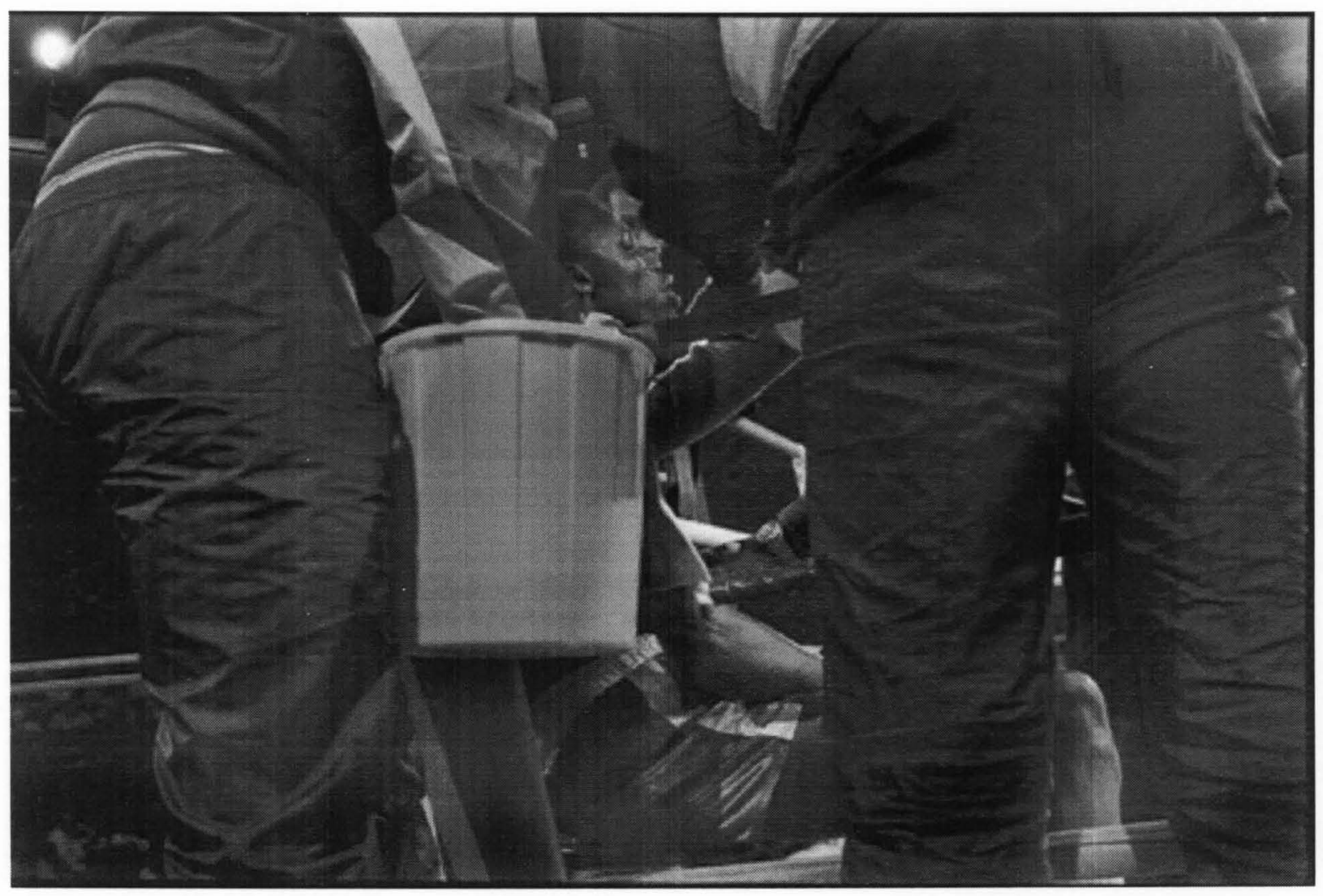

Figure 12

Johnny Bumphus, 1986

Gelatin silver print 


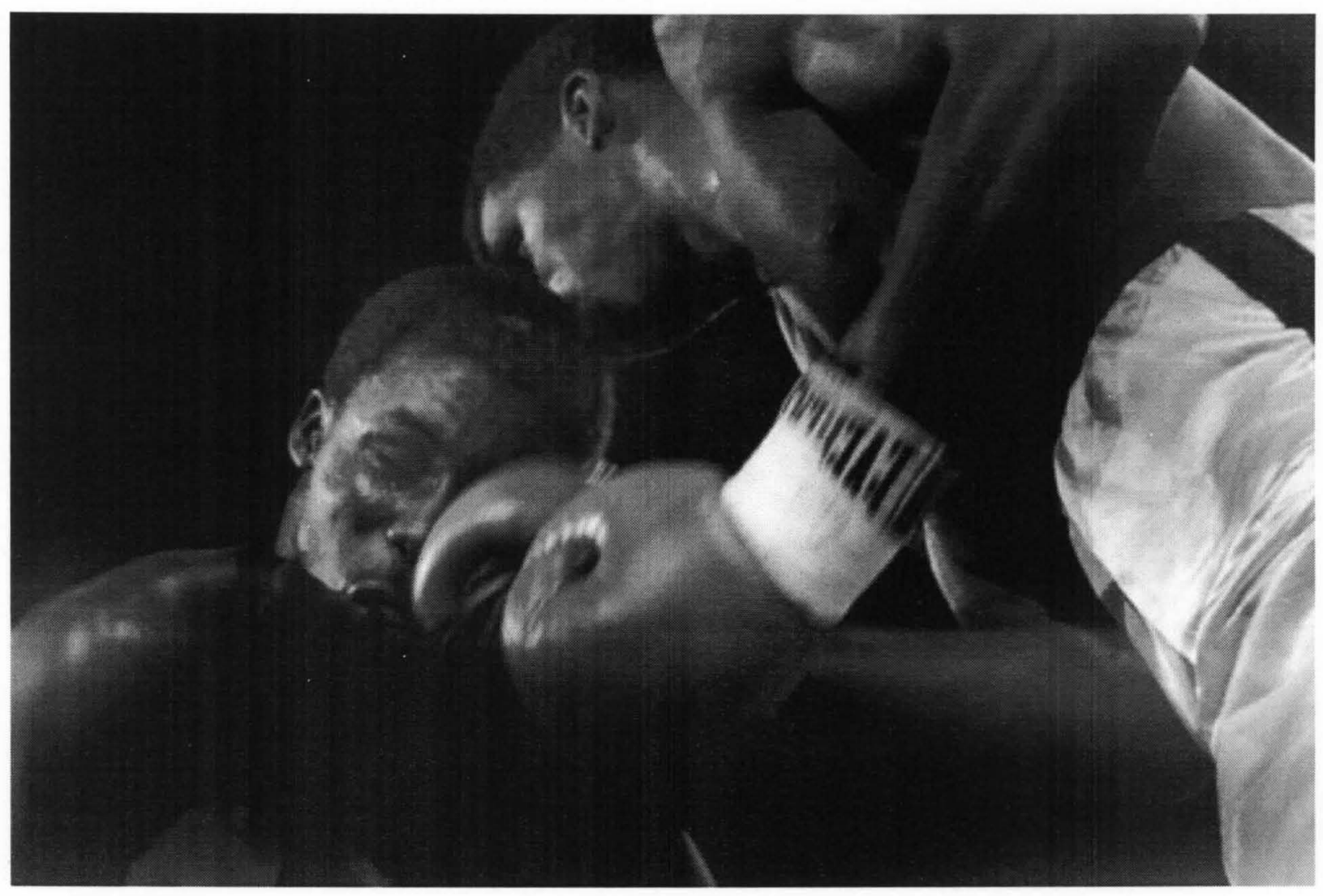

Figure 13

Andrews vs. Leach, Atlantic City, 1986

Gelatin silver print 


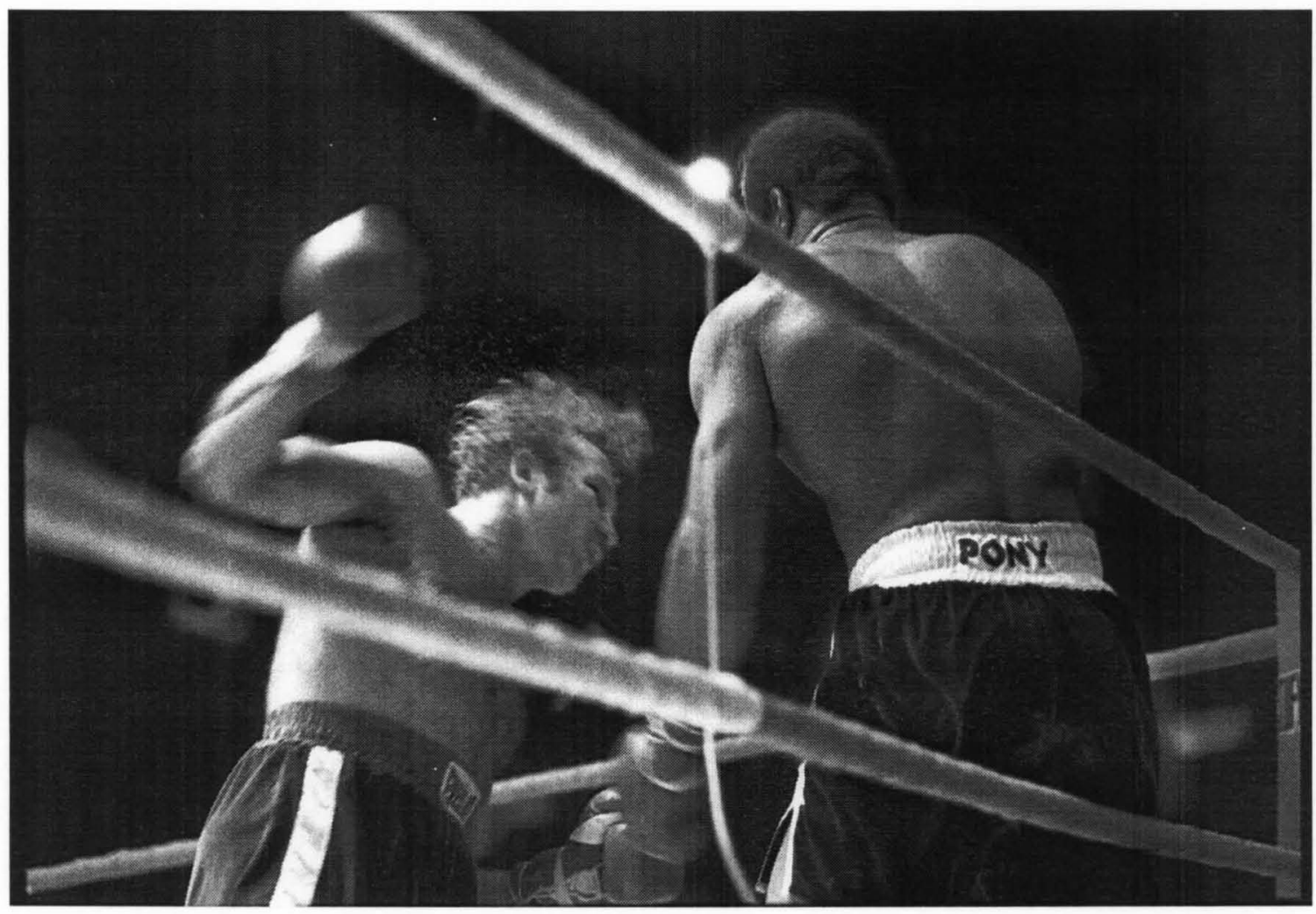

Figure 14

Scott LeDoux vs. Ken Norton, 1979

Digital ink-jet print 


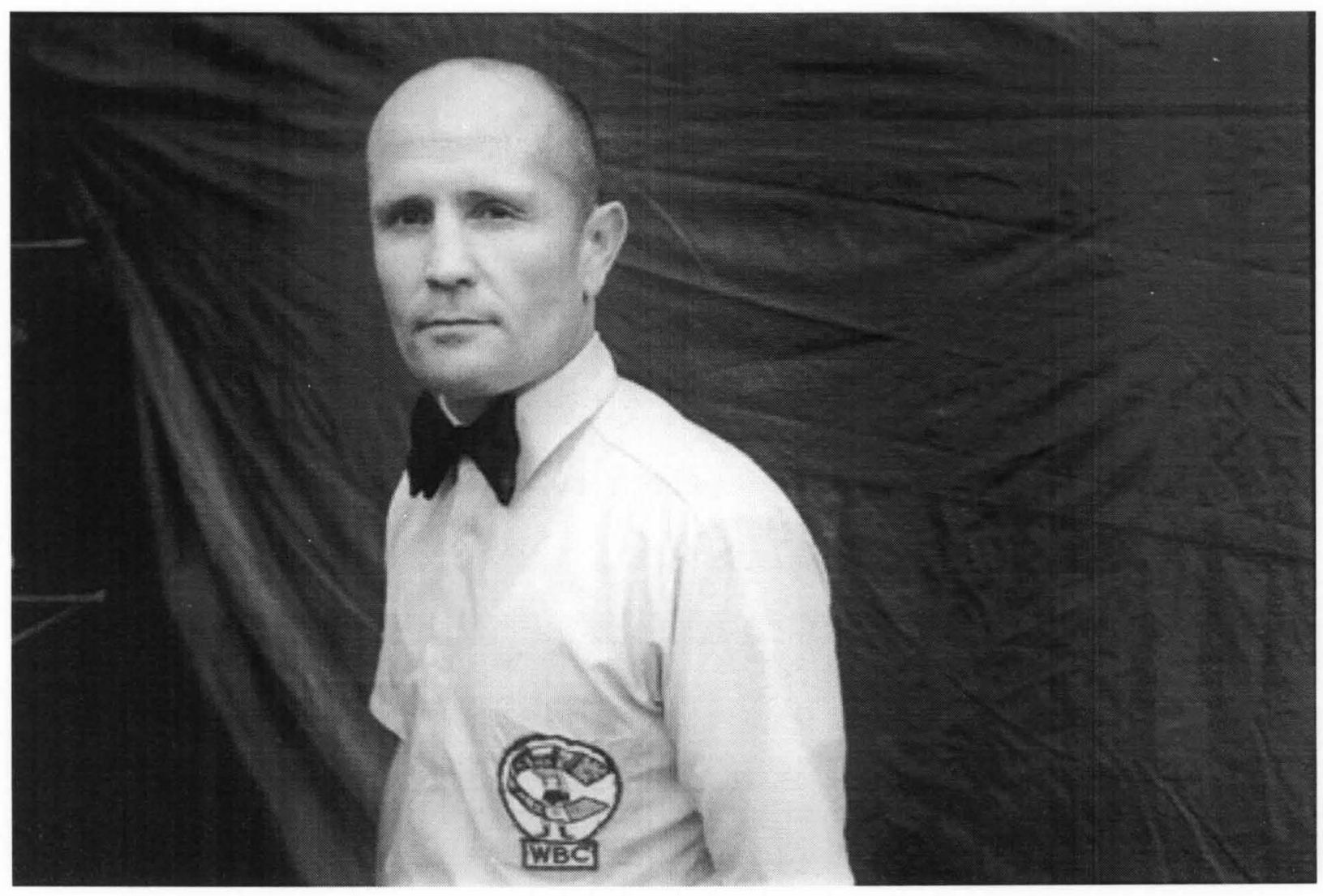

Figure 15

Mills Lane, Holmes - Clooney Bout, 1982

Gelatin silver print 


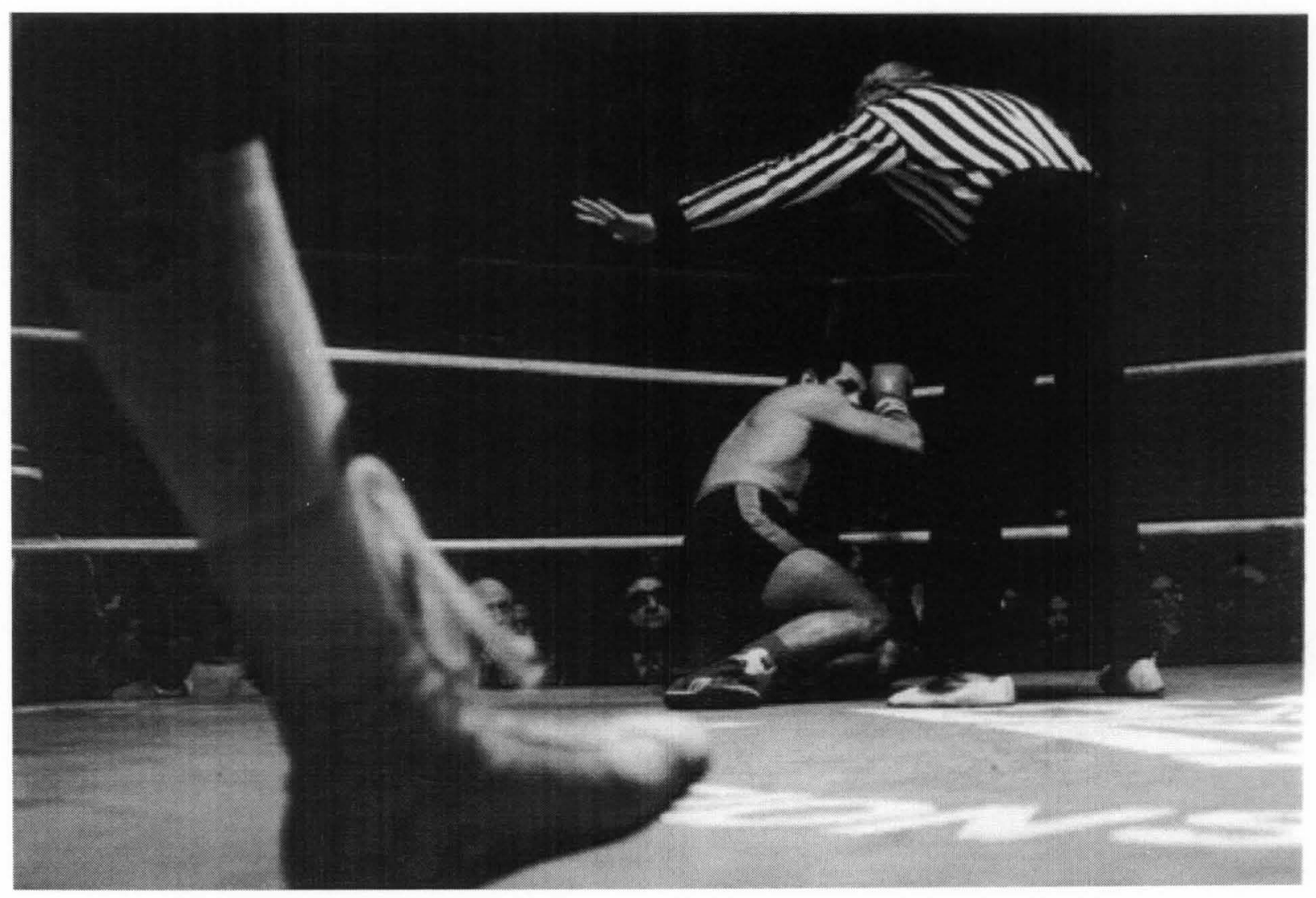

Figure 16

Victor Rodriguez (vs. Greg Page), 1980

Gelatin silver print 


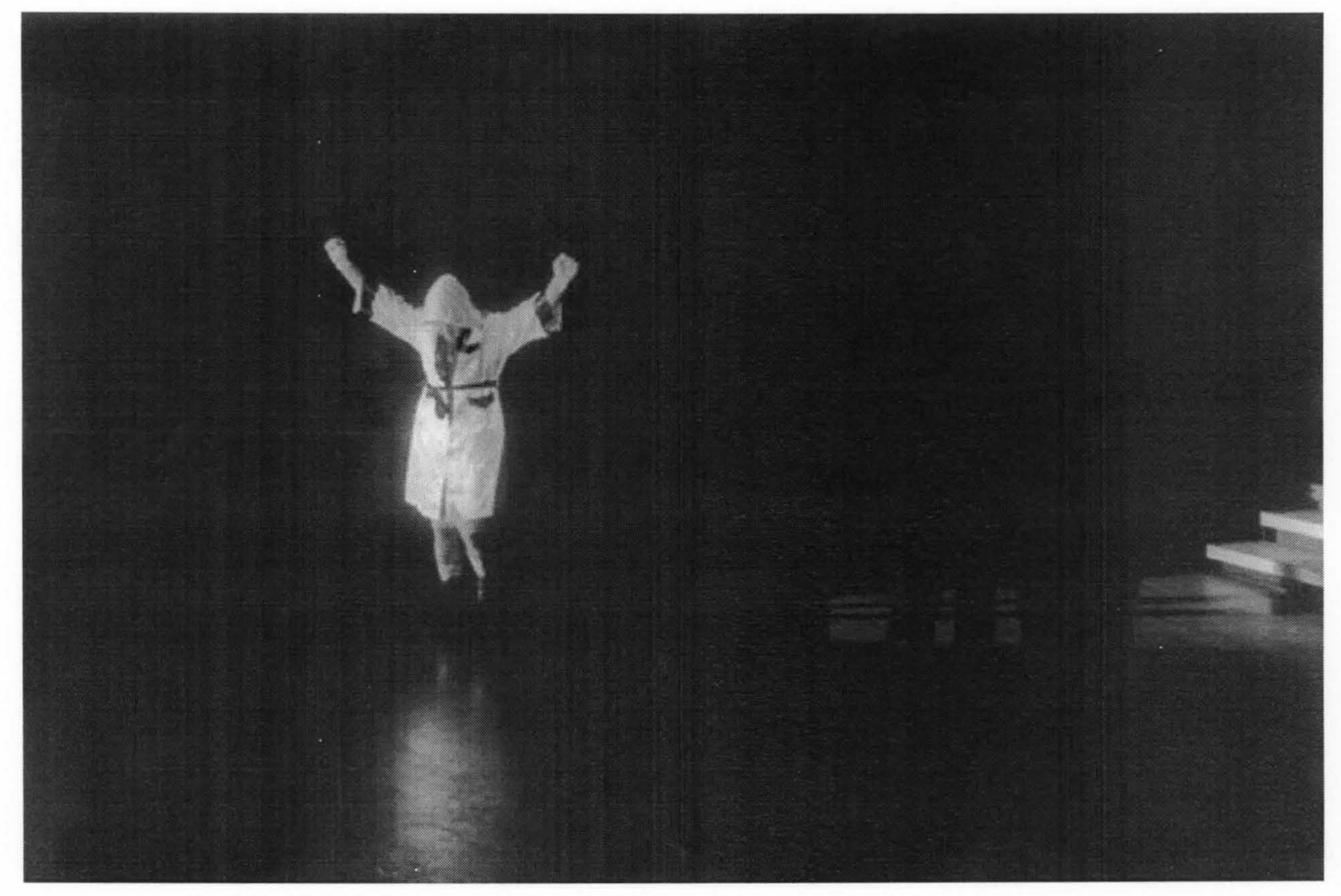

Figure 17

Baker Tinsley, 1979

Gelatin silver print 


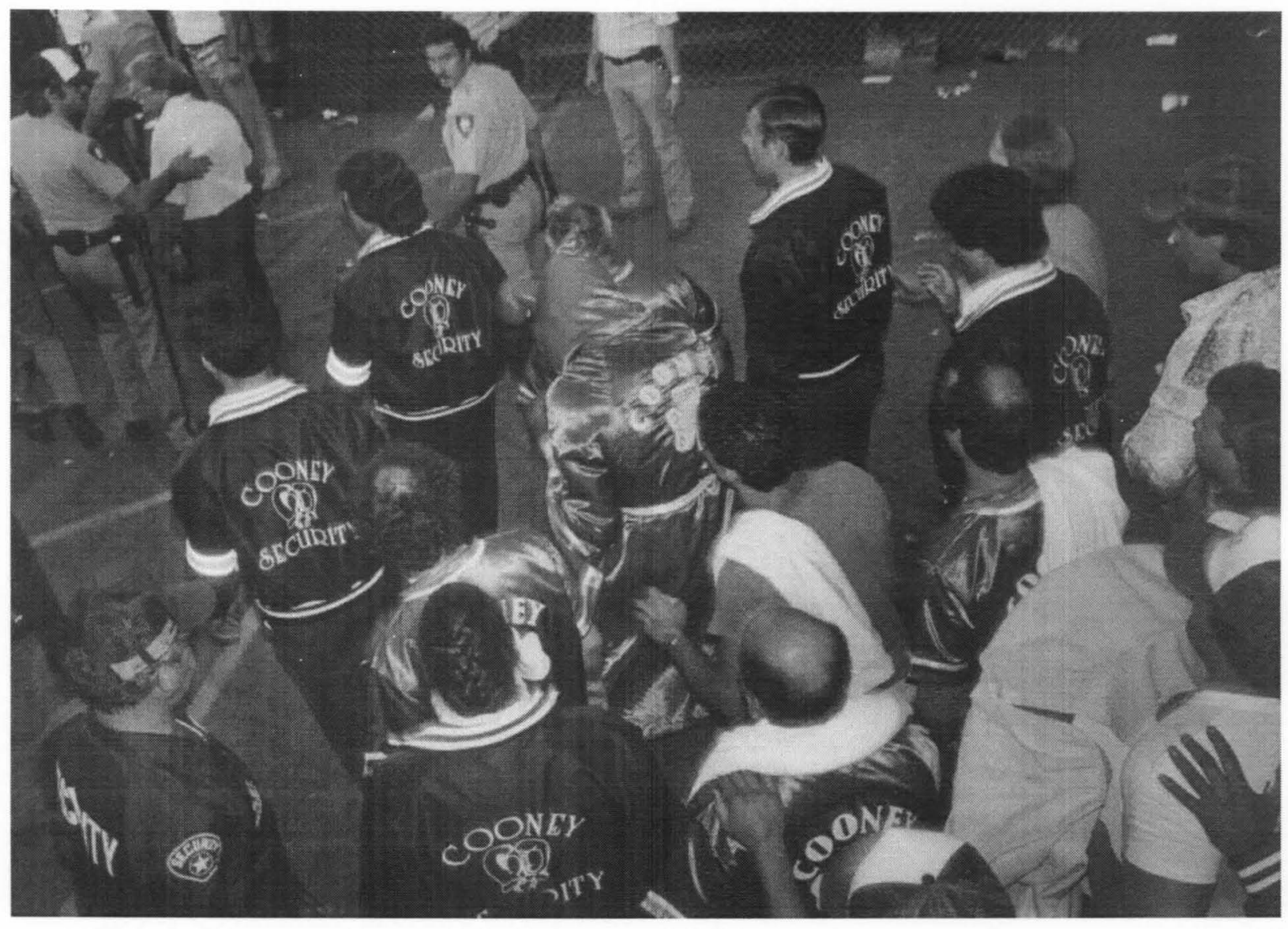

Figure 18

Cooney Security, 1982

Gelatin silver print 


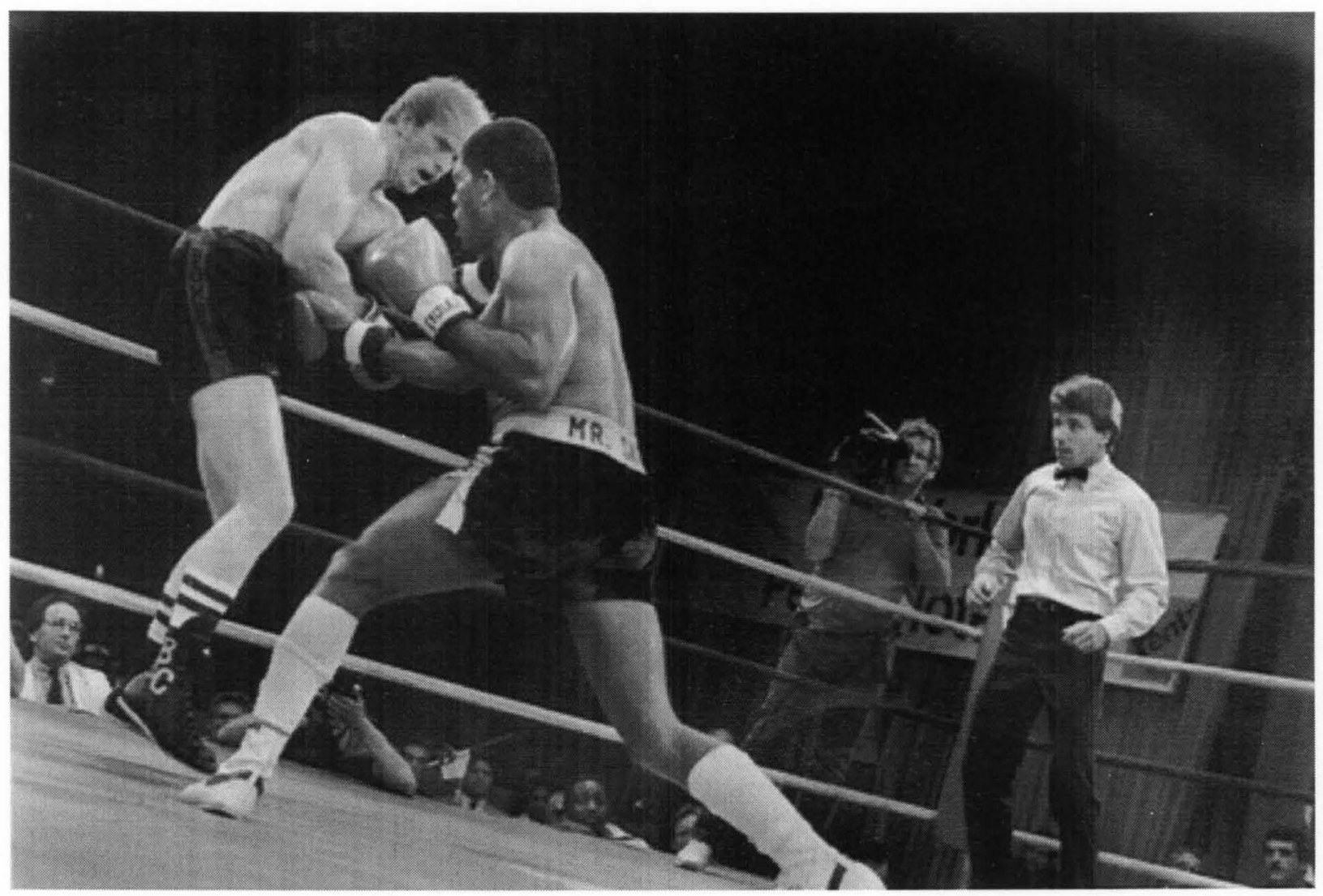

Figure 19

Renaldo Snipes vs. Bobby Crabtree, Felt Forum, 1988

Digital ink-jet print 


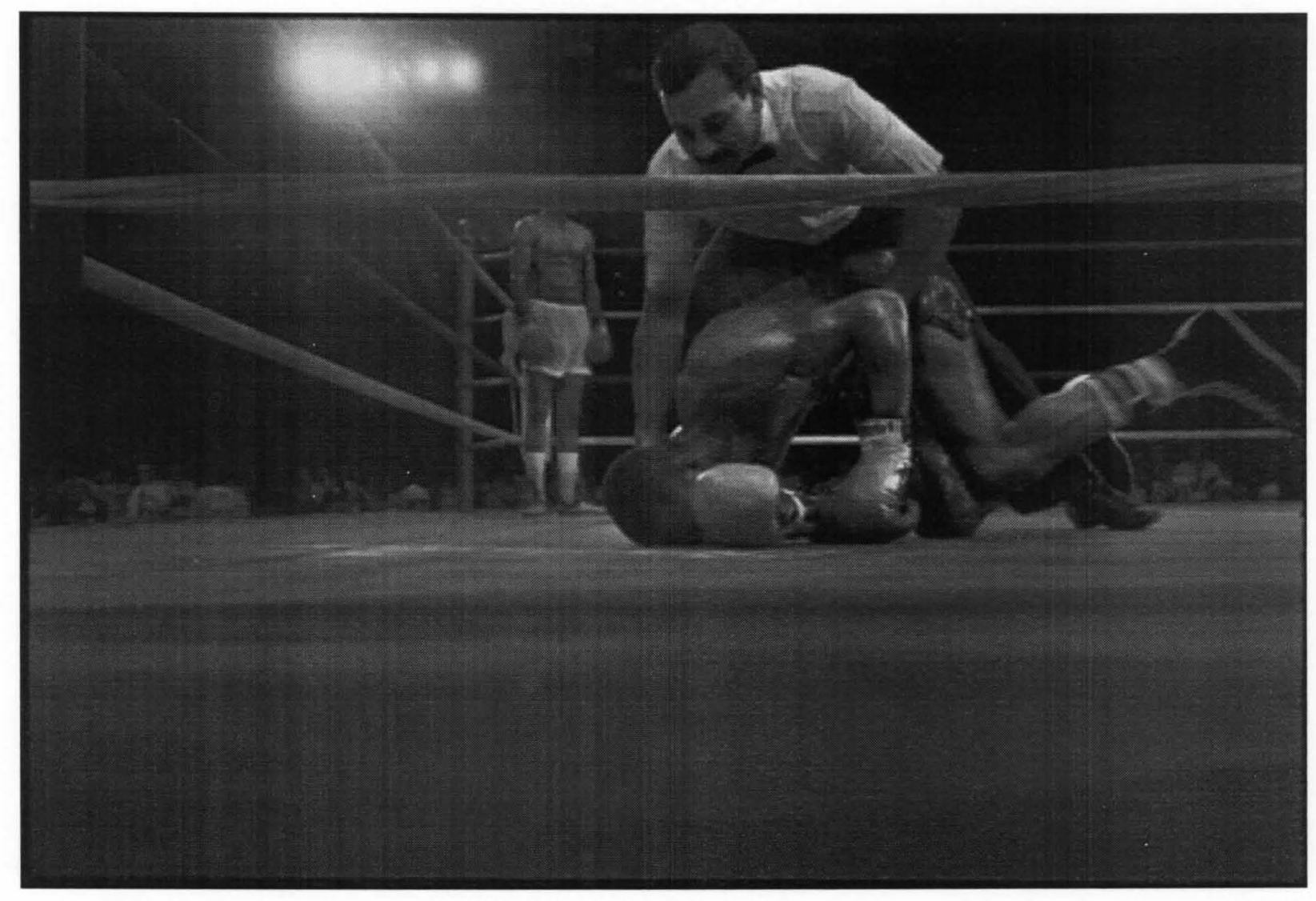

Figure 20

Willford Scypion vs. Iran Barkley, 1988

Digital ink-jet print 


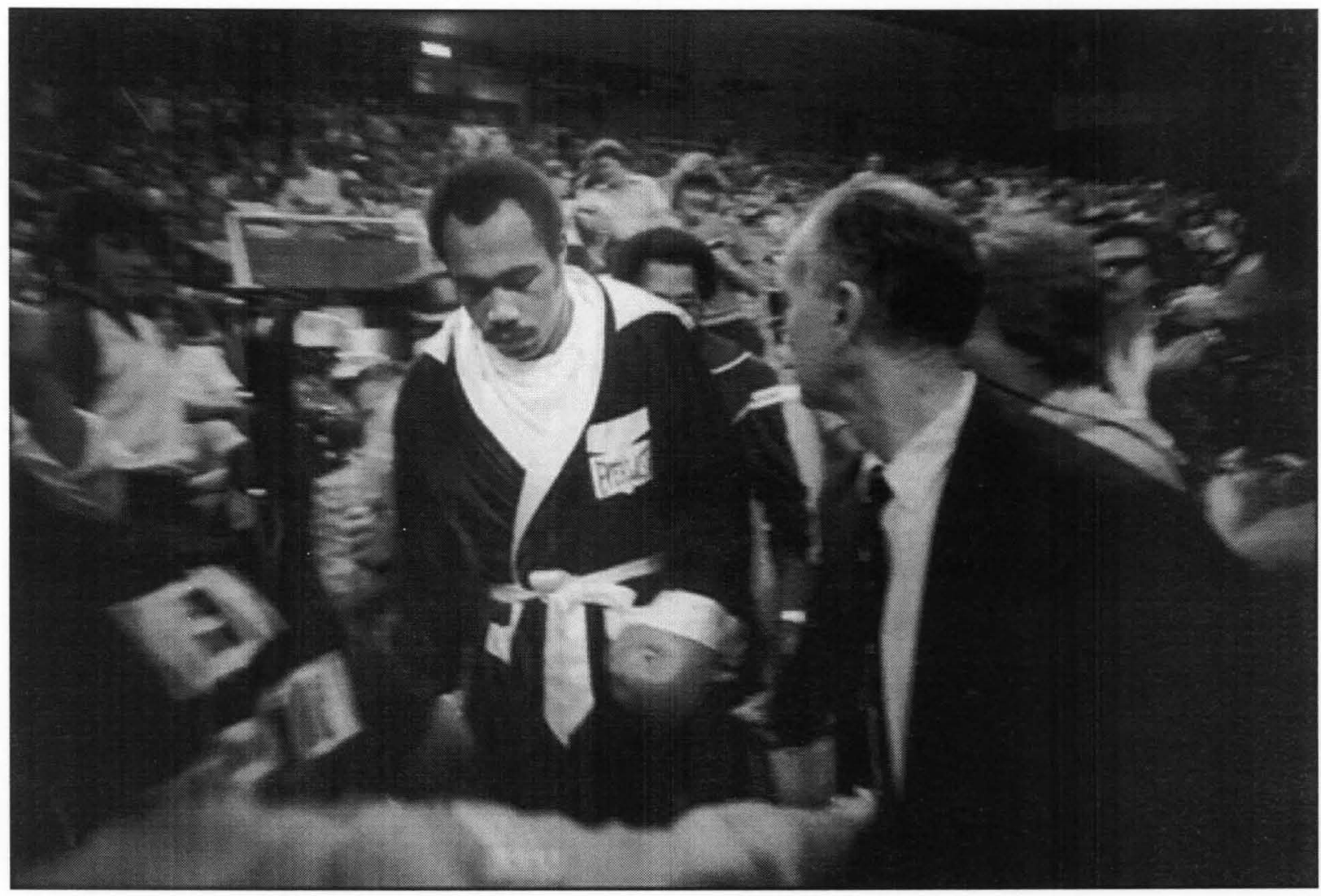

Figure 21

Ken Norton, 1979

Gelatin silver print 


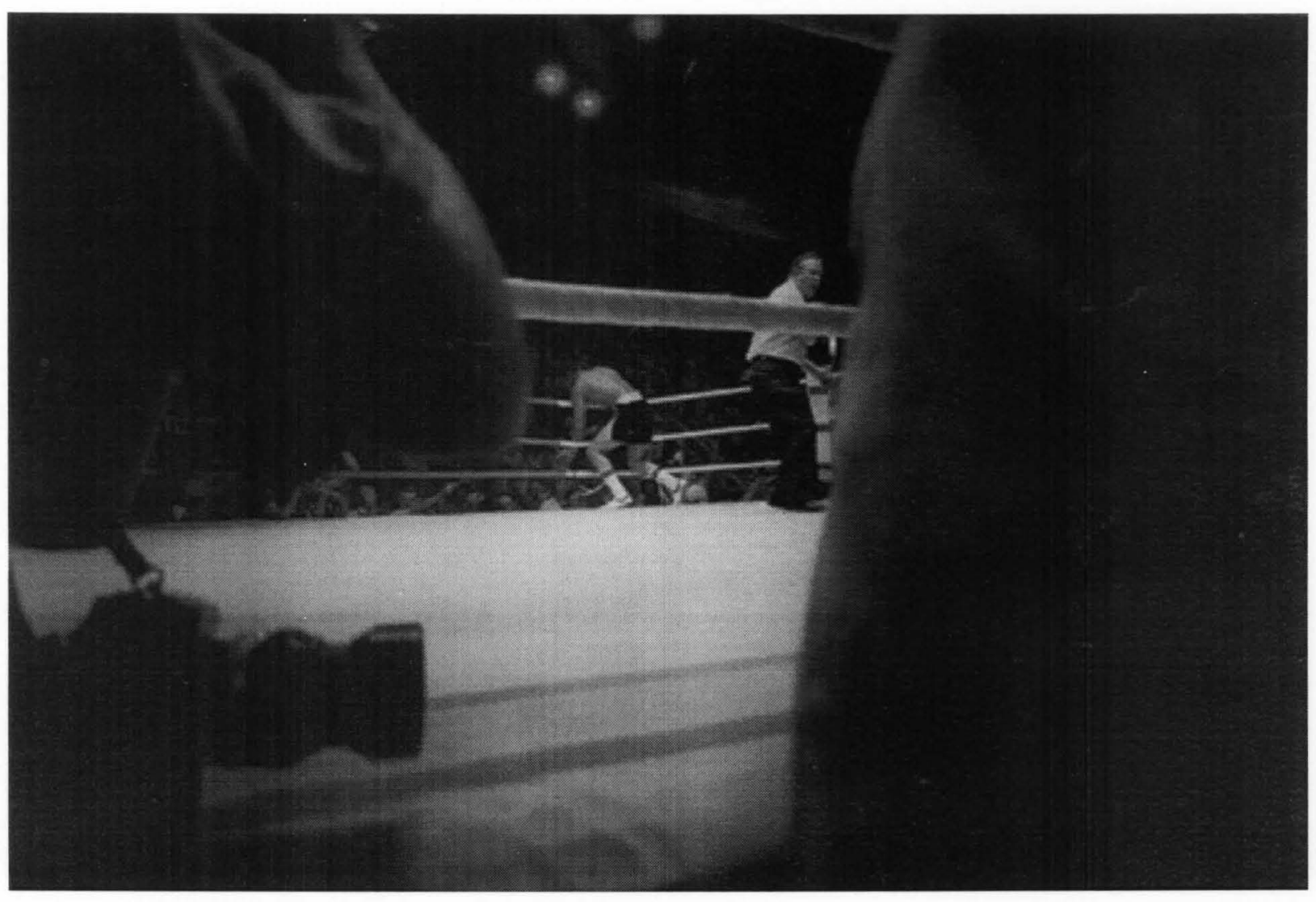

Figure 22

Ken Norton, 1979

Gelatin silver print 


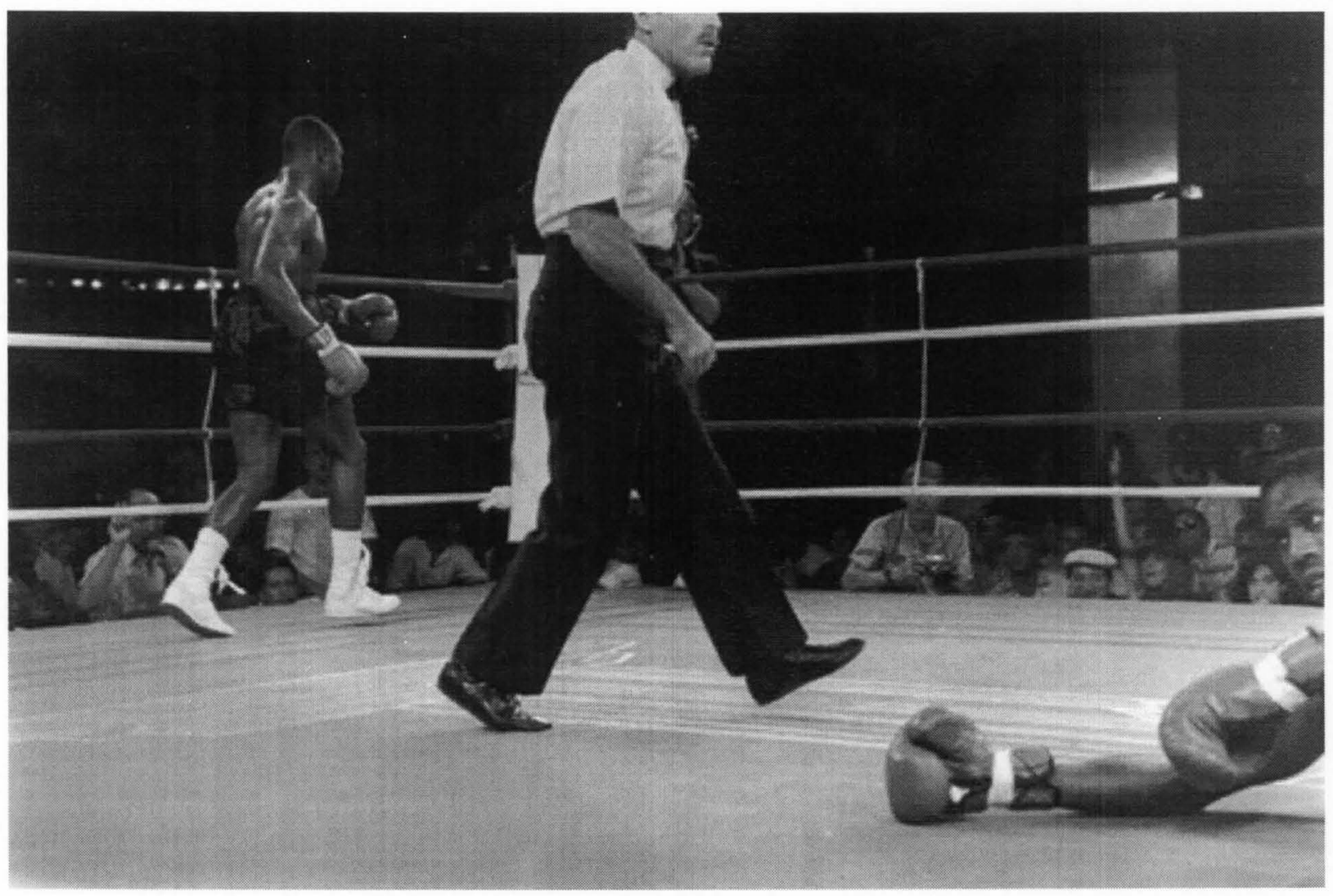

Figure 23

Tillman vs. Cooper, 1988

Digital ink-jet print 


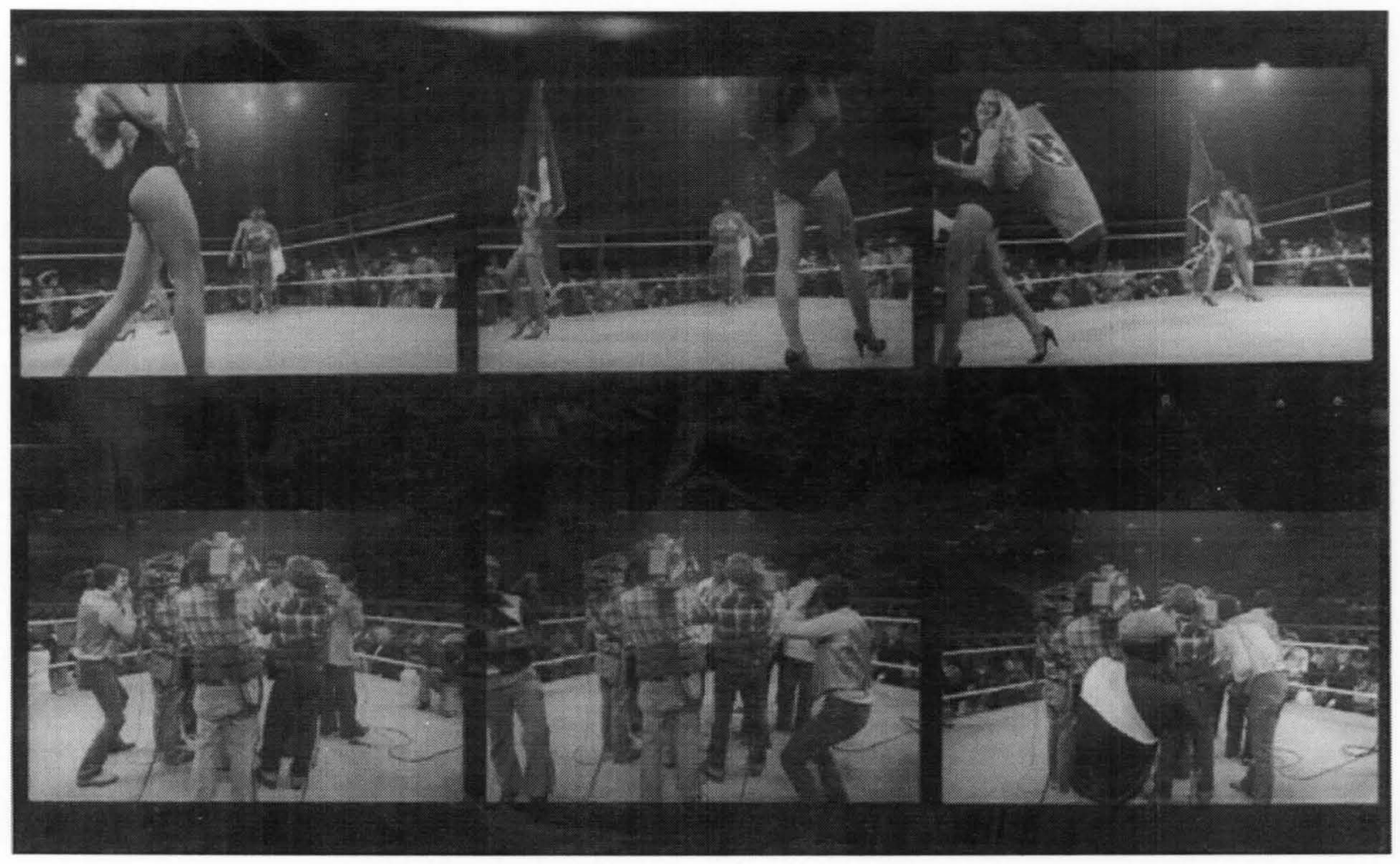

Figure 24

Greg Page's First Prizefight, 1979

Gelatin silver print 


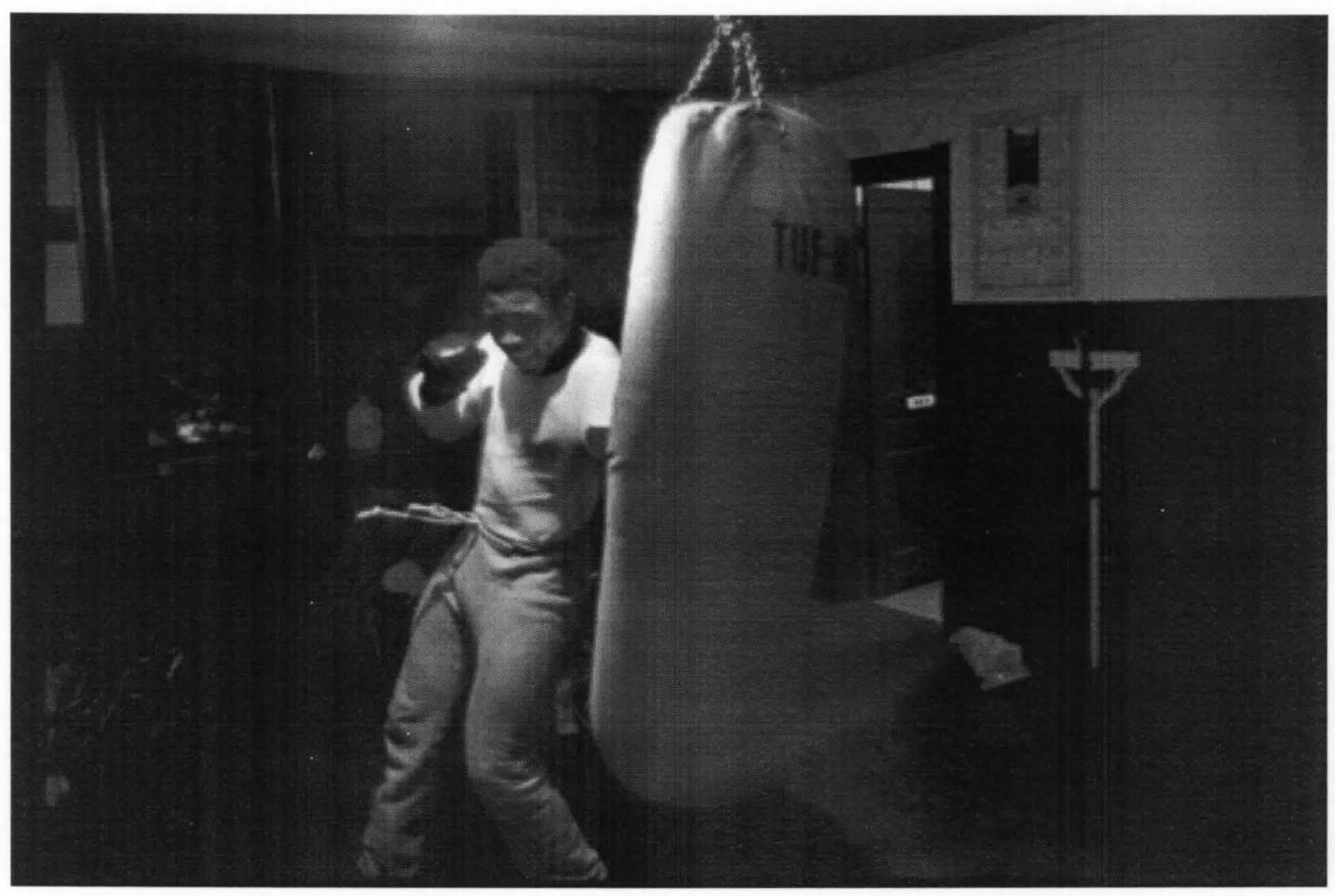

Figure 25

Greg Page at Baxter Gym, 1977

Gelatin silver print 


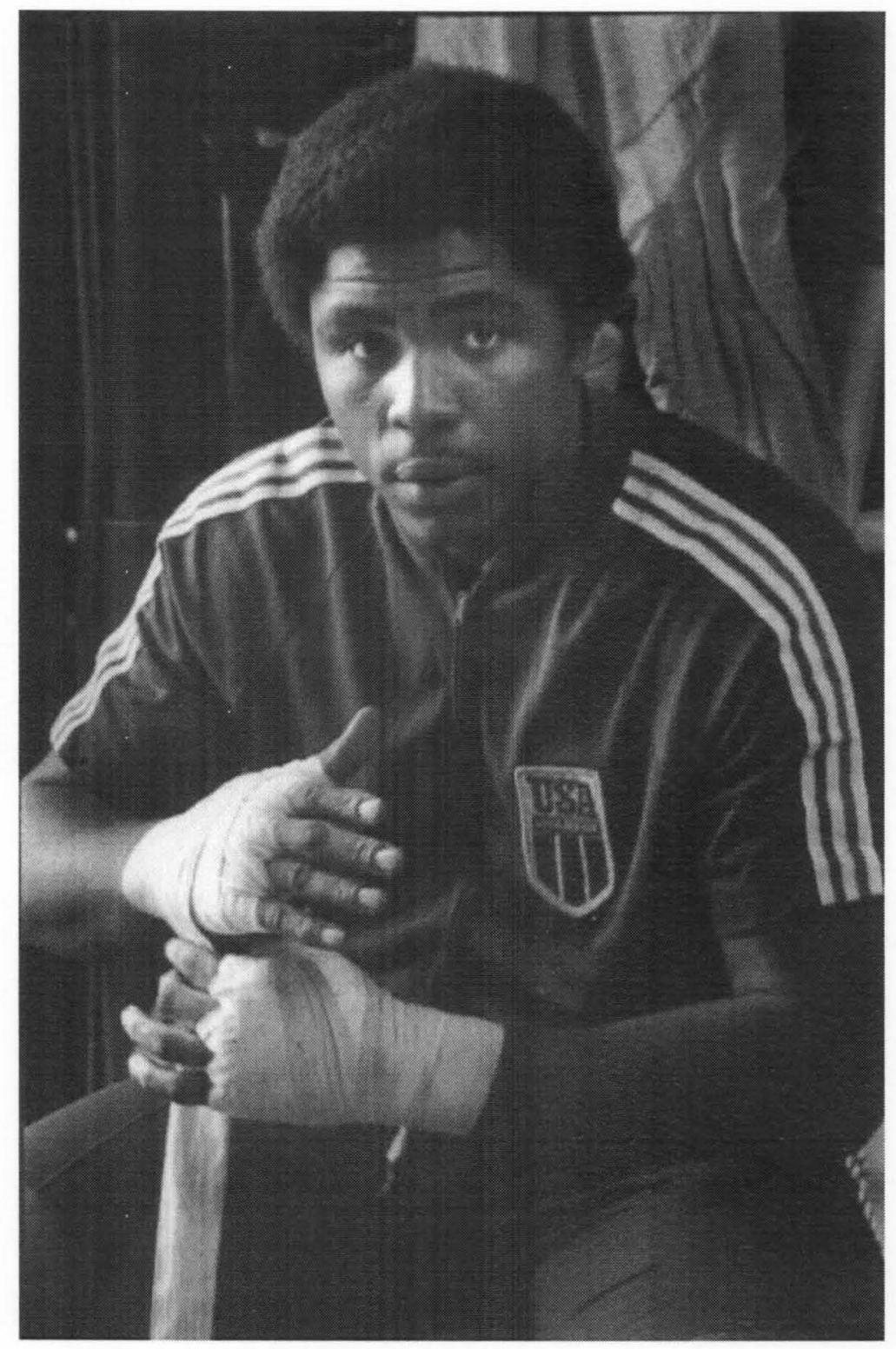

Figure 26

Greg Page, 1979

Gelatin silver print 


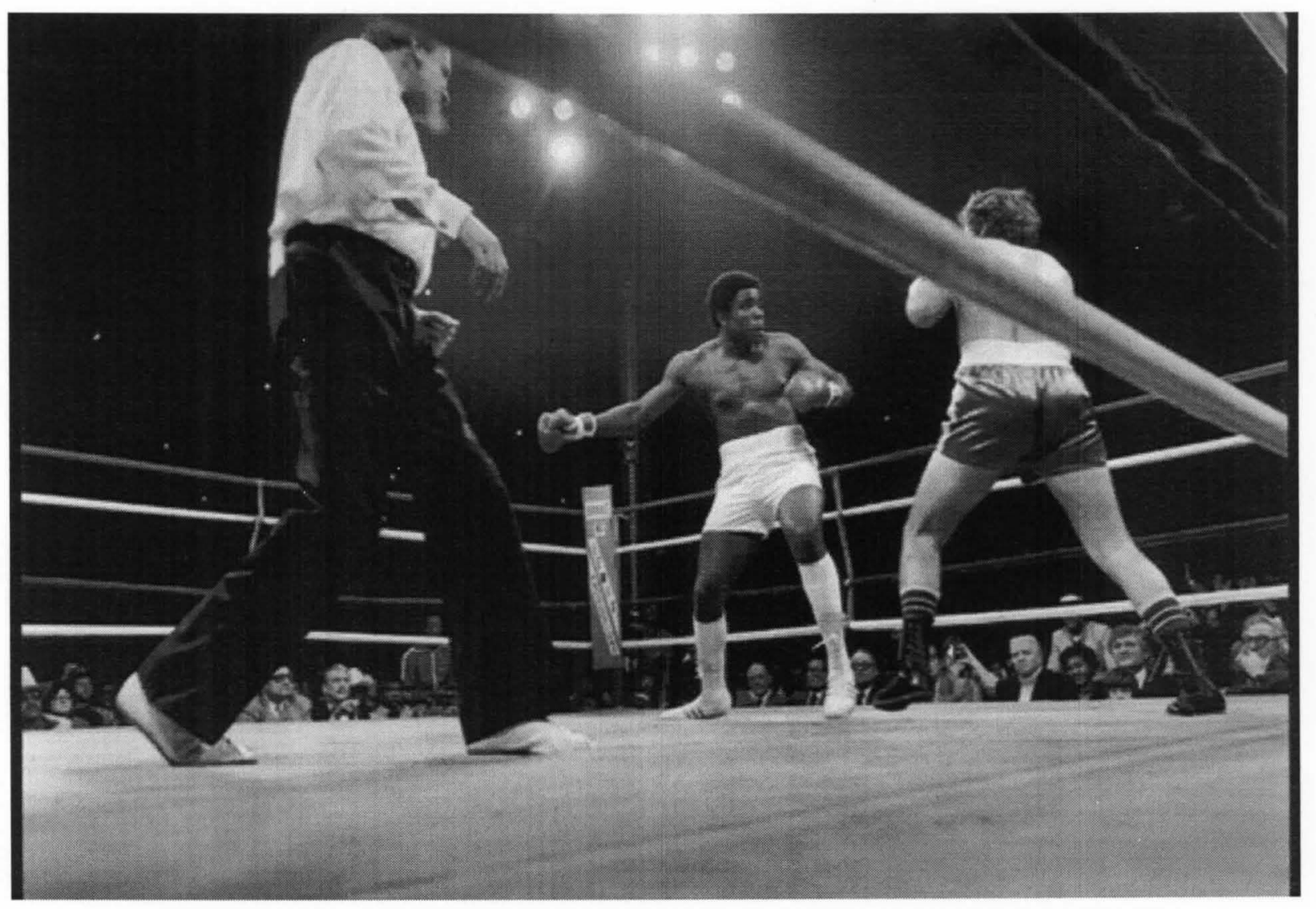

Figure 27

Greg Page vs. Don Martin, 1979

Gelatin silver print 


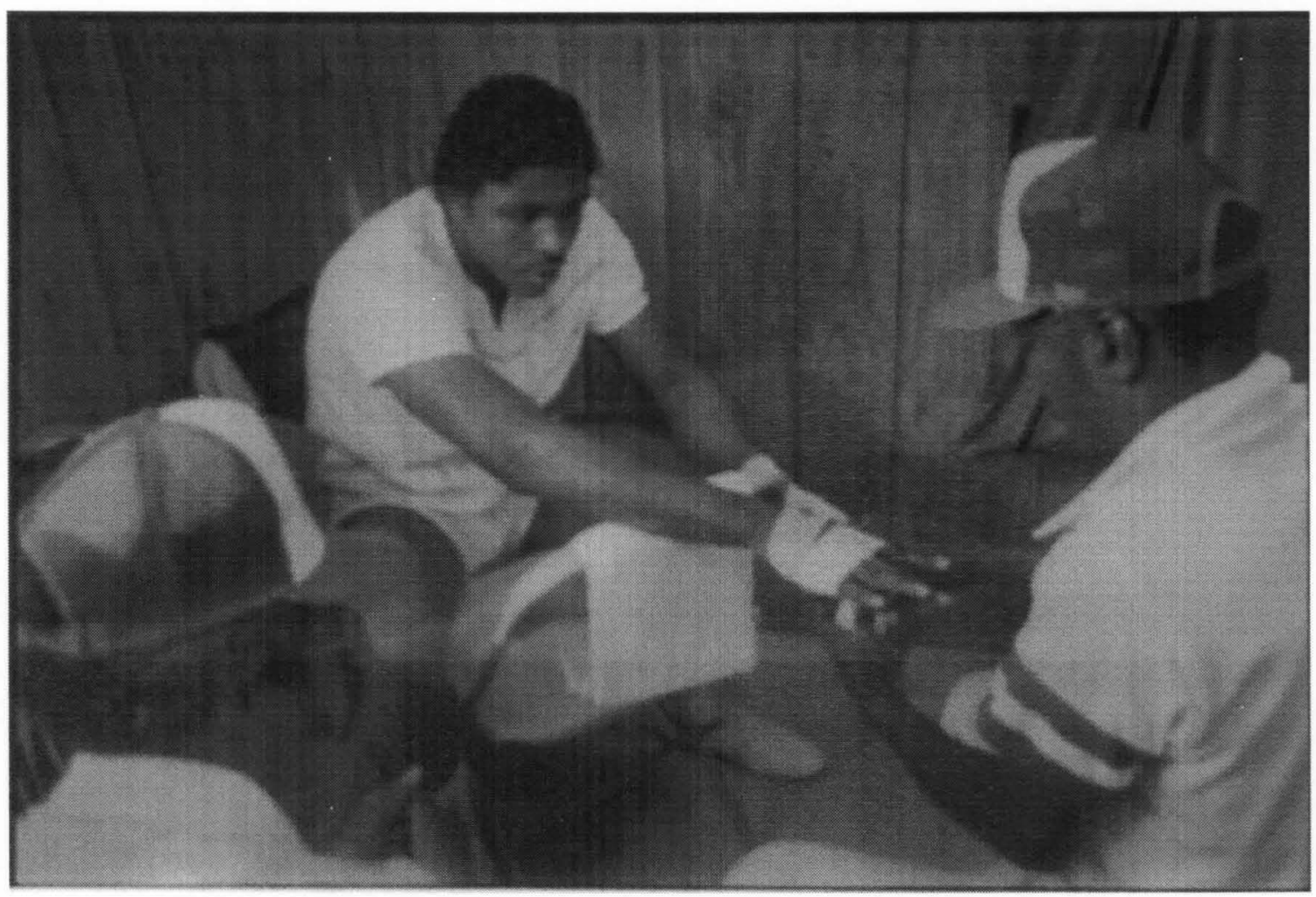

Figure 28

Greg Page vs. Trevor Berbick, 1982

Gelatin silver print 


\section{CHAPTER V}

\section{CREATING THE FINDING AID}

The collection of John Ranard's photographs, negatives, and ephemera brought to the University in 2009 numbered 56 boxes. These boxes differed in size and were a mix of archival and non-archival material: cardboard, tin, and plastic. After completing an assessment on the condition of the collection a year earlier and curating an exhibit from the work, I realized it would be helpful a to create a finding aid. The end product would allow curators to see the vast potential of the collection and expedite the construction of an exhibit.

At the time I began this project I was enrolled in Introduction to Archives (HIST-611). The class focused on archival principles and theories and their practical application and dealt with examples of processing collections of paper items: letters, maps, and books. The act of processing a collection involves description, arranging and storing in order to provide access to researchers and other users. Translating these examples and guidelines to working with photographs was not a difficult task. With my knowledge of Ranard's work and photograph preservation I was able to focus my time on the arranging and rehousing of the collection.

The class researched and discussed how the methodologies of processing have changed in the face of technology and the backlog of untouched 
acquisitions. The bulk of these discussions came from the "more product, less process" (Mark Greene/Meissner) movement that argues against many traditional processing steps in order to speed up the availability of records for the public. These were the most useful discussions for processing the Ranard collection due to the limited amount of time available to complete the task.

A fundamental concern with archivists is original order, the order in which the records were created. Almost since the beginning of his career, Ranard consistently marked his negative and contact sheets with dates and order of creation. Original order was noted but the materials were slightly out of order and stored within several boxes. Nonetheless, I was lucky. The most concerning part of the processing was working with the actual photographs. Ranard had a plethora of themes he photographed throughout his career. Since the University only has about half of his body of work, there were many photographs without negatives, and many photographs that could belong to more than one project. In researching Ranard's hard drive, I found up to seven titles for exhibit and book ideas based on his work in Russia. There was a very large cardboard box of unlabeled photographs and the box simply stated "Russia". I could easily determine which projects some of these photographs belonged to, others I could not. Those I placed in archival folders and labeled them "Russia, misc". Assigning certain photographs to titled folders and boxes became the biggest challenge.

While "more product, less process" speeds the processing of a collection, it can be a difficult method to maintain. In some cases it calls for omitting the 
need for original order. It seemed a disservice to rush through the arranging part of processing Ranard's collection, ignoring original order when he had taken care to keep these records himself. Ranard's collection contains many small, large, and branching themes. The categorization of themes was the most challenging to implement, partly because this was my first attempt but mostly because it is such a rich collection. I could not tear myself away from looking at every photograph. While this did not speed up the process I believe it lead to better arrangement of the collection.

The variety of themes in Ranard's collection struck me on a curatorial level and I arranged the photographs in this mindset. I started with the themes I was familiar with, those used for publications and ones I researched. Keeping original order within each of these themes, I arranged the materials into boxes and folders. I did not have time to catalog the pieces at an item level; I believe there to be over 100,000 pieces. The 'more product, less process' methodology was necessary for this project's completion.

Each box is arranged according to subject matters and then by date. The first box contains negatives and contact sheets from the mid 1970's, about the time Ranard was attending The Center for Photographic Studies in Louisville, KY. From the start Ranard was diligent at numbering and dating his rolls of film. Later he began to give titles to some and I used them when available. A few of the boxes contain one subject, those on Russia and boxing. While Ranard was photographing in Russia, he was also photographing on his visits to the States. Here I ignored the chronological organization for the sake of keeping the subject 
matter together. There are two large boxes of Russian negatives and contact sheets and one box with only Russian photographs. For the sake of research, I felt this would provide better access to the Russian subject matters.

Toward the end of arranging Ranard's collection I was left with small, family oriented subjects, projects without dates, and odd collections of ephemera that are not the work of Ranard. The subjects were separated into smaller boxes and folders, however the overall contents of the storage box are random. The finding aid works to provide insight into the collection and shows its value when dealing with storage boxes like this, one with seemingly random subjects.

\section{Conclusion}

The notations found in the physical collection and on Ranard's hard drive were invaluable in creating the finding aid. I processed the materials in accordance with archival methods and standards with the intention of creating accessibility to the materials for future exhibition projects. I realize this part of the project may only be an exercise in archival methods as the collection may not stay at the University. While the finding aid will provide guidance for this portion of Ranard's work, there is a disadvantage to the collection being separated. However, just this portion of Ranard's work inspires exhibition ideas and is worth the effort to note its content. It will be a valuable body of work when brought together, cared for, and readily accessible for curators, publishers, and researchers. 


\section{CHAPTER VI}

\section{THE FINDING AID}

John Ranard Photographs - temporarily housed at the University of Louisville

Processed by Marcy Werner

05/01/2012

Copyright date, University of Louisville

Title: The John Ranard Collection

Inclusive Dates: ca. 1976-2008

Call Numbers: NA

Accession Number: NA

Restrictions: Collection belongs to the Estate of John Ranard

\section{Biographical Note}

John Ranard (1952-2008) was a social documentary photographer. He focused his work on people and events on the fringes of society and of subcultures ignored or hidden from daily life.

Description of the Collection: The Ranard Collection consists of mostly black and white negatives, $\left(35 \mathrm{~mm}\right.$ and $\left.2 \frac{1}{4} \times 2 \frac{1}{4}, 4 \times 5\right)$ and images from the mid 1970 's to 2006. Subjects and locations photographed are extensive and wide. Most are from his years spent in Russia and document several themes he explored while there. Other subjects include Kentucky Derbys, the 1986 World Series of Poker, boxing, rodeos, squatters of Tompkins Square Park in New York, and self-portraits. Also present is his early work while at Louisville's Center for Photographic Studies, family photos, and correspondence. Also present is a $350 \mathrm{~GB}$ hard drive with digital images and layouts of book projects.

Provenance Statement: This collection is only half of Ranard's work. The other half is in storage in New York and is not included in this finding aid. The partial collection at the University of Louisville is housed in a climate controlled and secure storage facility on University grounds. The entire collection belongs to the Estate of John Ranard under the care of his brother, Andrew Ranard.

Description of some related materials: There is a small collection of color negatives and photographs by John Ranard. Also, there are several postcards addressed to Ranard as well as many exhibition announcements. 
Description of organizational process: The majority of the Ranard Collection consists of negatives and contact sheets. Most of the negative sleeves are labeled with dates and often a descriptive word. Where possible, negatives and contact sheets were matched up and placed in the same large storage box. Major themes have been housed together: Russia and Boxing, and smaller themes, Kentucky Derbys, weddings, Tompkins Square Park, and artists and musicians. The rest of the material is arranged in chronological order with small groups pulled and placed in folders.

\section{Container List of box numbers:}

Note: All photographs and negatives are black and white unless otherwise noted.

\section{Box 1- (Miscellaneous themes): contains negatives and contact sheets Boxes}

1.1 Kentucky Derby. 1978, 1982-83, 2000-2006. Negatives and contact sheets in black archival box.

1.2 Passages (artist title). 1986, April 16 to May 20. Negatives and contact sheets in cream archival box.

1.31984 World Series of Poker, May 14-17. Negatives only in cream archival box.

1.4 On Every Corner (artist title). 2006. Negatives and contact sheets in cream archival box.

1.5 Tompkins Square Park (artist title). Negatives and contact sheets in black archival box.

1.6 Tompkins Square Park Squatters. Negatives and contact sheets in black archival box.

\section{Folders}

1.1 1976-1977. Negatives and one contact sheet.

1.2 Early Louisville (artist title). Negatives only.

1.3 1985-1986. Negatives only.

1.4 Miscellaneous contact sheets, 1985-2000.

1.5 Paul Simon. 1987. Ceremony donating a Mobile Medical Unit in NY. Contact sheets only

1.6 New York sporting events. 1989. Contact sheets only.

1.7 Color slides. 1989. Miscellaneous subjects.

1.8 Vision Festival in New York, 200-2001. Color negatives only.

1.92001 Louisville exhibition. Negatives only.

1.102001 Berlin and Amsterdam exhibition. Negatives only.

1.11 Wynton Marsalis, House of Tribes. 2002. Negatives and contact sheets.

1.12 New York Dog Show, 2002. Negatives and contact sheets.

1.13 New York Dental Clinic, 2006. Negatives and contact sheets.

1.14 James Brown's viewing at the Apollo, 12/28/2006. Negatives and contact sheets.

1.15 Rodeo. 6 contact sheets. 
1.16 Roea and Emille. 4 contact sheets.

1.17 Jason Robards, Sissy Spacek, and other actors. 9 contact sheets.

1.18 Jesse Jackson and Joe Rose. 6 contact sheets. One photograph.

1.19 Musicians, miscellaneous. One negative sheet, 16 contact sheets.

1.20 Miscellaneous New York. Contact sheets and one sleeve of negatives.

1.21 Miscellaneous New York. Contact sheets only.

1.22 Miscellaneous. Contact sheets only.

1.23 New York dogs in Madison Park, 4/1989. Negatives only.

Box 2-(Russia 1992-1998): contains negatives and contact sheets Boxes

$2.12 \times 2$ negatives in glassine sleeves, 1992-1995 in gray archival box.

$2.235 \mathrm{~mm}$ negatives in poly sleeves, 1996

$2.335 \mathrm{~mm}$ negatives in poly sleeves AND contact sheets, 1997

$2.435 \mathrm{~mm}$ negatives in poly sleeves, 1998

Folders

2.1 Contact sheets, circa 1993-1995

2.2 Contact sheets, circa 1993-1995

2.3 Contact sheets, circa 1993-1995

2.4 Contact sheets, numbered, 1993

2.5 Contact sheets, numbered, 1994

2.6 Contact sheets, numbered, 1995

2.7 Contact sheets, numbered, 1995

2.8 Negatives and corresponding contact sheets, 1996

2.9 Contact sheets, numbered, 1996

2.10 Contact sheets, numbered, 1996

2.11 Contact sheets, numbered, 1998

2.12 Contact sheets, numbered, 1998

2.13 Contact sheets, numbered, 1998

2.14 Contact sheets, numbered, 1998

\section{Box 3- (Russia, 1999-2002): contains negatives and contact sheets} Boxes

3.1 Negatives and contact sheets, numbered, 1998 in cream archival box.

3.2 Negatives, numbered, 2000 in black archival box.

3.3 Negatives, numbered, 2001 in black archival box.

3.4 Negatives, numbered, 2002 in black archival box.

3.5 Printed mock-up for The Fire Within in red non-archival box.

Folders

3.1 Contact sheets, Ranard's order, numbered but not dated.

3.2 Contact sheets, numbered but not dated.

3.3 Contact sheets, numbered but not dated.

3.4 Contact sheets, numbered but not dated.

3.5 Contact sheets, numbered, 2001. 
3.6 Contact sheets, numbered, 2001.

3.7 Contact sheets, numbered, 2002.

3.8 Contact sheets, numbered, 2002.

Box 4- (The Boxing Photos): contains negatives, contact sheets, and prints Boxes

4.1 Signed boxing photos, $11 \times 17$ in black archival box.

4.2 Unsigned boxing photos, $11 \times 17$ in black archival box.

4.3 Signed boxing photos $(8 \times 10)$ and approx. 50 postcard-sized photos, signed/unsigned.

4.4 A blue 3-ring folder with 15 poly negative sheets. "Amateur Boxers in Louisville (KY), 1978-1982".

4.4a Unsigned $8 \times 10$ boxing photos.

4.5 16 envelopes of $35 \mathrm{~mm}$ negatives. Date range: Dec.1980 to Sept. 1986.

4.6 Approx. 206 glassine sleeves containing $35 \mathrm{~mm}$ negatives, 1986-1988.

Folders

4.1 Boxing, $35 \mathrm{~mm}$ contacts. Greg Page

4.2 Boxing, $35 \mathrm{~mm}$ contacts. Riddich Bowe.

4.3 Boxing, $35 \mathrm{~mm}$ contact sheets.

4.4 Boxing, $25 \mathrm{~mm}$ contact sheets.

\section{Box 5 (Russia prints): contains photographs/prints}

Boxes

5.1 Russia, misc. sizes, signed/unsigned. Black archival box.

5.2 Russia prison, signed and unsigned $11 \times 14$. Gray archival box

5.2a Russia, misc., signed. $8 \times 10$. Black archival box housed in box 5.2 .

5.3 Russia, misc., signed/unsigned, $8 \times 10$ and smaller. Cream archival box.

5.4 Chechnya, signed/unsigned, $8 \times 10$. Cream archival box.

5.5 Russia, drugs, signed. $8 \times 10$. Gray archival box.

5.6 Russia, medical and drugs, signed/unsigned. $5 \times 7$. Black archival box.

5.7 Russia, prints follow partial layout (included), $8 \times 10$. Black archival box.

5.8 Russia, misc. signed/unsigned. $8 \times 10$. Red non-archival box.

\section{Box 6 Miscellaneous themes. Contains photographs/contact sheets} Boxes

6.1 Russia, misc. mostly unsigned. $8 \times 10$ and postcards. Gray archival box.

6.2 Russia, misc. mostly unsigned. $8 \times 10$. Gray archival box.

6.3 Russia, drug photos. Signed, $11 \times 17$. Black archival box.

6.4 Russia, drug photos. Signed/unsigned, $11 \times 14,11 \times 17$. Black archival box.

Folders

6.1 Krzysztof Wodiczko's Polis Car, 1991. Prints and contact sheets.

6.2 Color portraits. $8 \times 10$.

6.3 Musicians, 1 contact sheet, 8 prints. 
6.4 Tompkins Square Park.

6.5 Amateur Night at the Apollo.

6.6 Comedians at The Comic Strip.

6.7 Kentucky Derbys.

6.8 New York City demonstrations.

6.9 Artists.

6.10 On Every Corner, 10 prints, 7 images.

6.11 Phonography, 6 prints.

6.12 Unidentified project. Negatives and photos.

6.13 Miscellaneous New York photos and portraits.

\section{Box 7 Miscellaneous themes. Contains photographs, negatives}

\section{Boxes}

7.1 Wedding work-Castrucci wedding and others. Photos and negatives. Gray archival box.

7.2 Weddings. Negatives and contact sheets. Black archival box.

7.3 Portraits. Color and b\&w and color slides. Black archival box.

7.4 Portraits. Negatives and contact sheets. Black archival box.

7.5 New York City and Gathering of Tribes, 1995-2006. Negatives and contact sheets.

7.6 Negatives. 1982-1984. National Finals Rodeo, Select Yearling Sale at Keeneland, Hawaii, and St. Petersburg, FL.

7.7 Negatives. 1976-Nov. 1978. Family, Kentucky, and Albuquerque.

7.8 Polaroid negatives. Misc. themes and times. Some photographs not by Ranard.

\section{Envelopes}

7.1 Negatives, Detroit.

7.2 Negatives, Jai Alice

Box 8 Miscellaneous themes. Contains photographs, negatives Boxes

8.1 Personal photographs and ephemera. Color photos, polaroids postcards, correspondence, wedding license.

8.2 Self-Portraits. Negatives and photographs. 'Last Days' self-portraits included.

8.3 Louisville and Kentucky. $8 \times 10$ photographs.

8.4 Miscellaneous panoramic negatives, some contact sheets. Circa 1999.

Four framed digital enlargements of passport photographs of Ranard.

Folders

8.1 Misc. exhibit postcards. Multiple shows, multiple copies.

One 320GB Toshiba hard drive: 262 GB used.

Contains digital photographs, jpgs and tiffs of several projects: 
The Brutal Aesthetic- boxing photos

On Every Corner- Louisville African-American church communities High Risk- Drug use in Russia

Forty Pounds- Life in post-Soviet Russia

Passport, Lost Heroes- Immigrants in NY

Family Album

NYC, 2002

Weddings

Tandem Spiral- Russia

Survival, Evasion, Escape- Russia

Prisoners- Russia prisons

The Fire Within- Russia

HIV in Russia

Self-portraits

Cell phone photographs, color

Misc. software programs

Formats of files: Word documents, jpgs, tiffs, Canon Raw, pdfs, 


\section{CHAPTER VII}

\section{CONCLUSION}

\section{The Exhibition}

The Brutal Aesthetic and the opportunity to work with an admired local institution was an incredible and privileged experience. The project used my multi-tasking abilities and challenged me to develop my academic and research side. The small amount of detective work required with this project has prompted me to seek out additional and equally compelling independent projects in curatorial and archival fields. My personal background as a photographer helped to shape decisions made and helped me to look at Ranard's photos as more than simply photographs of boxers.

This exhibition sought to expand upon the published photographs of John Ranard. His photographs speak to the physicality of the sport without touching on the often-argued savagery involved. They are not gratuitous; they are beautiful. Ranard self identified as a social documentary photographer but many of his images reflect a deep knowledge of art and art history. His thoughtful compositions transport his photographs into this realm and his technical knowledge of equipment and printing complete the process. 


\section{The Finding Aid}

The finding aid project sharpened my skills of investigation and research and challenged the organization methods of a traditional archive. While Ranard maintained his collection in a loose order of subject matter, his brief notations, acronyms, and initials used prompted me to make connections. It was also a discovery of the lack of scholarly writings on contemporary events and issues. I do not know how difficult this process would have been without the internet. It felt like luck each time I stumbled across bits of information. I am embarrassed how long it took me to figure the meaning of initials Ranard used to label several boxes. For example, TPS, stands for Tompkins Square Park. It was only after looking at the photographs of young, disheveled, and seemingly homeless people in New York that I connected the dates, city, and "TPS" into a search to find the meaning. The amount of writing on the subject was enough to make me understand Ranard's motivation to become involved with these people and their struggles.

Discovering that Ranard was present and documenting some of the now historic moments in New York was a gateway into exploring these events on a different level. The breadth of information and inspiration available in this small collection of photographs and negatives is stunning. Little has been written on many of the worthy subjects he widely documented. Researchers and writers interested in contemporary issues, those from the mid 1980's to early 2000's, 
and events like New York City's squatters' rights protests (Moynihan) and other demonstrations would find this collection akin to a treasure chest.

The estate collection needs to be complete for optimal impact in creating comprehensive exhibits and continuing to find opportunities for these photographs. While Ranard seemed to have kept most of his work categorized by subject matter, there are negatives with no prints, and visa-versa. That more boxing photographs may exist that could have better or more fully illustrated the Ali Center's mission is a possibility that should be addressed for the integrity of the artist and the work. Viewers will see what they want in his photographs but choosing those that closely align with his intentions would be the best way to honor his work. Having the complete archive of Ranard's work would help ensure future curators and researchers to assess and demonstrate his breadth of involvement and importance in contemporary history and social issues. 


\section{REFERENCES}

Carner, Bill. Photo Wrangler. Interview, 9 September, 2010.

Castrucci, Andrew. "Remembering John Ranard." 8 September, 2008. http://www.tribes.org/web/2008/09/08/remembering-john-ranard-wordsfrom-the-memorial/

Greene, Mark A. and Dennis Meissner. "More Product, Less Process: Pragmatically Revamping Traditional Processing Approaches to Deal with Late $20^{\text {th }}$-Century Collections." PDF, 2005.

Keish, Kathleen, "Art: Exhibit pays tribute to late photographer John Ranard." Leo Weekly, 1 July, 2009.

Martin, Douglas, "Greg Page, Heavyweight Champion, Dies at 50." New York Times, 28 April, 2009.

Merriam-Webster Online. http://www.merriam-webster.com/

Oates, Joyce Carol, On Boxing. Dolphin/Doubleday, 1987. Garden City, New York

Schudel, Matt. "Photographer John Ranard; Showed Dark Side of Life." Washington Post 16 June 2008. 


\section{APPENDIX}

\section{EXHIBITION TEXT}

\section{FROM THE ALI CENTER}

The Muhammad Ali Center is proud to present "The Brutal Aesthetic," a photographic exploration of boxing by John Ranard. Many of the photographs were taken in Louisville and feature local boxers, including Greg Page. In the hands of John Ranard, black-and-white photography is the perfect canvas for uncovering the stark contrasts of the boxing world.

The extraordinary heights attained by Muhammad Ali intersect with the storytelling of "The Brutal Aesthetic" in the core values displayed throughout the Center. These values, such as confidence, conviction, and dedication, inspire and drive individuals to find their greatness within, wherever that path may lead them.

The moments captured by Ranard illustrate that the road to glory is a long and arduous journey often born of humble beginnings, not unlike those of Muhammad Ali. Those that seek greatness travel a path that requires dedication and sacrifice. Each quest is punctuated by opportunities and life-changing moments. For some, it is supported by a bit of luck. Yet, for all, the path to greatness is both brutal and beautiful, solitary and spectacle.

Ranard's work goes beyond defining boxing, to provide a unique and intensely personal interpretation of the "sweet science" that combines familiar scenes with private moments that are unexpected and often unseen. 
"A prizefight is like a war; the real part is won or lost...behind the lines, in the gym and out here on the road long before I dance under those lights." --Muhammad Ali, The Greatest My Own Story

\section{ABOUT THE EXHIBIT}

As a social documentary photographer, John Ranard was interested in various groups and subcultures. While living in Louisville he became immersed in the world of boxing, forming a close relationship with future Heavyweight Champion Greg Page. These photographs document the early days of Page and many others in the boxing world, from Louisville and beyond.

The physicality of the sport is present in many photographs but each contains a hint of the contemplative, subtle, and surprising moments occurring both in and out of the ring. It is Ranard's unique talent and skill that captured those instances. These moments create a means of empathy for the viewer. We see boxers shed their hero-like status to reveal vulnerability, if only for a second.

"It began by photographing a community of amateur and professional prizefighters who trained in a gym within a short walk from my Louisville, Kentucky apartment. The result was a five year journey that brought me to New York's three month long Golden Gloves tournament."

These photographs were taken from 1976 to 2001 . Many are from a body of work titled "The Brutal Aesthetic" and were published in On Boxing by Joyce Carol Oates, 1986. 


\section{ABOUT THE ARTIST}

The son of a Foreign Service officer, John Ranard spent his childhood living abroad in Japan, Malaysia, Korea, Burma, and Australia. These experiences set the stage for a lifelong curiosity of unique cultures. Ranard developed his documentary style of investigating cultures while attending the Center for Photographic Studies in Louisville, KY in the late 1970's. Soon Ranard began contributing to various alternative Louisville publications, such as City Paper and later, Louisville Today. During this period he developed a feature called "Ranard's Picture Show" which he carried on to New York's, The Villager.

In the early 1980 s, Ranard traveled the country photographing various sporting events. He assembled the photos of the boxing world into a book titled The Brutal Aesthetic, which he unsuccessfully sought to publish. It was this series, however, that won him the Kentucky Arts Council's Al Smith Fellowship in 1987.

Ranard may be best known for his prize-winning documentation of the AIDS crisis in Russia that appeared in the New York Times in 1997 (OSI). His work was supported by grants from Doctors Without Borders and the Soros Foundation Open Society. AIDS Foundation EastlWest published many of these photographs in media campaigns throughout Russia.

In 2006 Ranard returned to Louisville and began a photo series about race and class tensions. It became a moving documentation of small nondenominational churches and their communities in Louisville's West End. Referring to the plethora of these churches, the series is titled, "On Every 
Corner". Later that year Ranard discovered he required a liver transplant. He began to photograph the physical struggles of a recovery that would not happen as his new liver became cancerous. Severely underweight, he captured the progression of his condition in his final self-portraits (Ranard). John Ranard passed away on May 14th, 2008. He was 56 years old.

\section{GREG PAGE}

Greg Page started his boxing career when he was a child, training with his father in Louisville, KY. When he was 15 years old he sparred with Muhammad Ali who remarked, "That boy hit me so hard it jarred my kinfolk back in Africa."

By the time he became the National Golden Gloves heavyweight champion in 1978 at age 20 , he was considered one of the greatest of amateurs with a record of $94-11$.

As a professional, he was considered talented but undisciplined and dealt with the constant pressure of being compared to fellow Louisvillian, Muhammad Ali. He lost his first shot at the World Boxing Association heavyweight championship in 1984 to Tim Witherspoon, however in December of that year, Page knocked out Gerrie Coetzee of South Africa to claim the title.

Page left fighting in 1993 but returned to the ring in 1996 and proceeded to win 20 of 25 of his bouts. In 2001 he fought his last fight. The infamous fight put Page in a coma for a week and caused him permanent brain damage and paralysis. Lack of immediate medical attention at the boxing facility led to his condition. He later underwent brain surgery but never regained his mobility. Complications lead to his death on April $27^{\text {th }}, 2009$. 
Page's family wants him remembered as a fighter - not just in the ring - but also in his battle against a paralyzing brain injury. His legacy lives on in the Greg Page Safety Initiative, a set of codes that brought Kentucky's boxing regulations on par with those of federal standards (Kenning).

Page would have been 53 years old this October $25^{\text {th }}$.

\section{Figure 6 and 7}

Ring card girls were first used in Las Vegas in the 1950's as a way to hold the audience's interest between rounds and as an attempt to gain more viewers. They not only inform the audience of the upcoming round, but sometimes provide a bit of entertainment as well (Ireland).

\section{Figure 9}

Contrapposto is an Italian term used to describe a pose in which the figure places most of their weight on one leg. This pose was explored in Greek and Renaissance art. Ranard's knowledge of art, keen eye, and timing allowed him to capture Davis at a moment that likens him to a classical sculpture.

\section{Figure 10}

The famous Bedford-Stuyvesant Boxing Club, during its prime in the 1980's, produced world champion boxers Michael Bentt and Mark Breland, as well as Tunde Foster, Brian Adams, Ernest Mateen and Riddick Bowe (Farrell). 


\section{Figure 15}

Mills Lane had a long career officiating several major heavyweight championship boxing matches from 1971 to 1998 . Lane became widely known outside of boxing when he disqualified Mike Tyson in his match with Evander Holyfield, in which Tyson bit Holyfield's ear twice.

Marc Ratner, former director of the Nevada Athletic Commission said of Mill Lane, "What Mills had was the respect of the boxers. When he issued voice commands, the fighters listened. For a man small in stature, he had a big presence about him. (Carp)"

\section{Figure 21}

Ken Norton is best known for going up against Muhammad Ali in 1973. Norton won the fight and some boxing experts call it one of the most memorable fights of all time. Later that same year, in another bout against Ali, Norton lost in a split decision. In 1976 the two heavyweights met a final time for the title. Norton lost again in a split decision that was highly disputed.

Norton was inducted into the Boxing Hall of Fame in 1992 (International Boxing Hall of Fame). 


\section{REFERENCES}

Carp, Steve, "Stroke Victim Mills Lane, family cope." Las Vegas Review-Journal, Nov. 9, 2008. <http://www.lvrj.com/news/34166084.html>.

Farrell, Bill, "Bed-stuy Gym May be Ko'd.” New York Daily News, 14 Nov. 1996. <http://articles.nydailynews.com/1996-11-14/local/18023006_1_boxingclub-landlord-lease>.

"Ken Norton," International Boxing Hall of Fame, <http://www.ibhof.com/pages/about/inductees/modern/norton.html>.

Ireland, Jae, "What Are the Girls Who Walk Around the Boxing Rings Between Rounds." Livestrong.com, 14 June 2011. $<\mathrm{http}$ ://www.livestrong.com/article/422685-what-are-the-girls-who-walkaround-the-boxing-rings-between-rounds/>.

Kenning, Chris, "Page remembered for tough fights in and out of ring." USA Today, 4 May 2009. <http://usatoday30.usatoday.com/sports/boxing/200905-04-page-funeral_N.htm>.

Open Society Foundations. "OSI Mourns Passing of Documentary Photographer John Ranard." Press release, 14 May 2008.

$<$ http://www.opensocietyfoundations.org/press-releases/osi-mournspassing-documentary-photographer-john-ranard>.

Ranard, Andrew and Lincoln Anderson. "John Ranard, 56, social-documentary photographer." The Villager 21-27 May 2008. $<$ http://www.tribes.org/web/2008/09/08/remembering-john-ranard-wordsfrom-the-memorial/s. 


\section{BIBLIOGRAPHY}

Brunton, Paul and Tim Robinson. "Arrangement and Description" Keeping Archives, $2^{\text {nd }}$ ed. , Judith Ellis, ed. (Port Melbourne, Vic: Australian Society of Archivists, 1993) 222-247. Print.

Carp, Steve. "Stroke Victim Mills Lane, family cope." Las Vegas Review-Journal, Las Vegas, NV. Nov. 9, 2008. <http://www.lvrj.com/news/34166084.html>.

Castrucci, Andrew. "Remembering John Ranard-Words from the Memorial." $A$ Gathering of Tribes 8 September 2008. $<$ http://www.tribes.org/web/2008/09/08/remembering-john-ranard-wordsfrom-the-memorial/s.

Desnoyers, Megan Floyd. "When is a Collection Processed?" The Midwestern Archivist VII, no. 1 (1982): 5-23.

Edgecombe, Jennifer. "Finding Aids," Keeping Archives, $2^{\text {nd }}$ ed., Judith Ellis, ed.

(Port Melbourne, Vic: Australian Society of Archivists, 1993) 248-272.

Farrell, Bill. "Bed-stuy Gym May be Ko'd." New York Daily News, New York, NY. Nov. 14, 1996. <http://articles.nydailynews.com/1996-1114/local/18023006_1_boxing-club-landlord-lease>.

Giachino, Alyssa. "Madina mosque is Muslim cab drivers' spiritual stop." The Villager, New York, NY. May 16-22, 2007.

http://thevillager.com/villager_211/madinamosqueismuslim.html.

Greene, Mark A. and Dennis Meissner. "More Product, Less Process:

Revamping Traditional Archival Processing," American Archivist 68: 208263, 2005.

Hughes, Philip. Exhibition Design. London: Lawrence King Publishing Ltd., 2010. Print.

"Ken Norton". International Boxing Hall of Fame website. $<$ http://www.ibhof.com/pages/about/inductees/modern/norton.html>. 
Ireland, Jae. "What Are the Girls Who Walk Around the Boxing Rings Between Rounds." Livestrong.com, June 14, 2011.

$<$ http://www.livestrong.com/article/422685-what-are-the-girls-who-walkaround-the-boxing-rings-between-rounds/>.

Keish, Kathleen. "Art: Exhibit pays tribute to late photographer John Ranard." Leo Weekly (Magazine). July 1, 2009. < http://leoweekly.com/ae/art-exhibitpays-tribute-late-photographer-john-ranard $>$.

Kenning, Chris. "Page remembered for tough fights in and out of ring." USA Today, May 4, 2009.

<http://usatoday30.usatoday.com/sports/boxing/2009-05-04-pagefuneral_N.htm>.

Martin, Douglas. "Greg Page, Heavyweight Champion, Dies at 50." New York Times, New York, NY. April 28, 2009. <http://www.nytimes.com/2009/04/29/sports/othersports/29page.html?_r= $0>$.

McFadden, Robert D. "Park Curfew Protest Erupts into Battle and 38 are Injured." New York Times, New York, NY. August 8, 1988.

$<$ http://www.nytimes.com/1988/08/08/nyregion/park-curfew-protest-eruptsinto-a-battle-and-38-are-injured. $h$ tml?pagewanted=all\&src=pm>.

Meehan, Jennifer. "Making the Leap from Parts to Whole: Evidence and Inference in Archival Arrangement and Description" American Archivist 72 (Spring/Summer 2009): 72-90. Print.

Moynihan, Colin. "20 Years After Unrest, Class Tensions Have Faded and Punk Rock Will Be Played," New York Times. August 2, 2008. <http://www.nytimes.com/2008/08/02/nyregion/02tompkins.html>.

Need, Lynda. "Stilling the Punch: Boxing, Violence and the Photographic Image." Journal of Visual Culture (Vol. 10 (3), 2011): 305-323. Print.

Oates, Joyce Carol. On Boxing. Garden City, New York: Dolphin/Doubleday, 1987. Print.

Open Society Foundations. "OSI Mourns Passing of Documentary Photographer John Ranard." Press release, May 14, 2008.

<http://www.opensocietyfoundations.org/press-releases/osi-mournspassing-documentary-photographer-john-ranard>. 
Ranard, Andrew and Lincoln Anderson. "John Ranard, 56, social-documentary photographer." The Villager, New York, NY. 21-27 May 2008.

$<$ http://www.tribes.org/web/2008/09/08/remembering-john-ranard-wordsfrom-the-memorial/>.

Schreiner, Maggie. "Housing Struggles in the East Village: 1970 to $1990 . "$ <http://aphdigital.org/GVH/exhibits/show/housing-in-the-east-village--1>.

Schudel, Matt. "Photographer John Ranard; Showed Dark Side of Life." Washington Post, Washington D.C. 16 June 2008.

$<\mathrm{http}: / / \mathrm{www}$.washingtonpost.com/wpdyn/content/article/2008/06/15/AR2008061501841.html>.

Sekula, Allan. "Dismantling Modernism, Reinventing Documentary (Notes on the Politics of Representation)." The Massachusetts Review, (Vol. 19 (4), 1978): 859-883. Print.

Szarkowski, John and Hilton Als. "Looking at Pictures." Grand Street, (No. 59, 1997): 102-121. Print.

Zinkham, Helena. "Use, Value, Viability: Criteria for Choosing Effective Processing Levels for Visual Materials." SAA/NAGRA Annual Meeting, 8/3/2006. Print. 


\section{CURRICULUM VITAE}

\section{Marcy Rae Werner}

Phone: 502- 644-5146

Email: marcy.rae1@gmail.com

\section{Experience}

Louisville Slugger Museum and Factory- 8/2011-5/2012, Intern -Assistant Curator

${ }^{*}$ Accessioning the Museum's collection.

*Photographing and entering collection into Past Perfect software.

${ }^{*}$ Researching items to create accurate and thorough inventory descriptions.

*Assisting acquiring objects for exhibits, creating label copy, exhibit layout, and condition reporting.

${ }^{*}$ Assisting in handling, storing, and shipping a variety of artifacts and materials from baseballs to paintings, clothing to stadium lights and everything in between.

University of Louisville, 6/09 - 05/2012

Graduate Teaching Assistantship 08/2010 - 05/2012

${ }^{*}$ Created syllabi, lesson plans, and taught Drawing and Design studio classes for the 2010/2011, 2011/2012 school years.

08/2010

University Libraries Archives and Digital Collections 01/2010 -

*Used Better Light large format scanning camera equipment to create digital files of the University's archive holdings.

*Handled historical photographs, maps, and holdings from 1835-present.

Humana Inc, 9/07 - 6/09, Medicare Contract Specialist

${ }^{*}$ Created contracts to government regulations and customer requirements.

*Documented progress of project flow through weekly status reports.

*Prioritized running projects based on demand and fluctuating timelines.

Ashley Furniture, 12/03 - 9/07, Visual Merchandising Store Manager

${ }^{*}$ Creatively merchandised 55,000 sq. ft. showroom.

*Hired, trained, and developed visual merchandising staff.

*Ran and utilized sales reports, remained knowledgeable of trends, and observed shopping habits to evaluate and maximize product sell-through. *Ensured accurate inventory through weekly checks. 
Kenmark Group, 4/01 - 12/03, Marketing/Special Project Manager

*Designed sales booth layout for various trade shows in the eyewear industry. ${ }^{*}$ Organized and implemented seasonal and yearly, customer promotions.

*Wrote press releases and e-mail updates to trade magazines.

*Managed imagery used for all marketing and advertising efforts.

Cinderblock Gallery, 6/01-6/04, Co-operated gallery

${ }^{*}$ Created themes for monthly exhibits and sought artists for participation.

*Installed exhibitions and maintained gallery condition.

*Designed marketing and promotional materials.

*Wrote and assembled press packets for local publications.

Kentucky Museum of Art and Craft, $12 / 97$ - 4/01, Director of Gallery Sales

${ }^{*}$ Curated yearly show of Kentucky metalsmiths.

*Prepared and reported strategic sales plan to Board of Directors.

${ }^{*}$ Ordered, inventoried, and merchandised works from over 500 artists.

${ }^{*}$ Trained sales staff in all areas of retail.

${ }^{*}$ Organized and headed the jury process for crafts shown in the Museum.

${ }^{*}$ Assisted in storing, shipping, and handling of art.

Internships

University of Louisville's Photographic Archives- 4/2011 - 7/2011, Intern

*Digitized a collection of photographs for the University's Digital Collection.

${ }^{*}$ Researched, wrote introductory matter and descriptions for the collection http://digital.library.louisville.edu/collections/furnas/

${ }^{*}$ Cataloged initial collections in Archivist Toolkit.

${ }^{*}$ Completed condition reports for Blake prints and illustrations.

Kentucky Historical Society- 1/2011 - 4/2011, Intern

*Digitized oral histories from cassettes, CDs, and videotape.

${ }^{*}$ Researched large oral history interview collection for exhibit use.

${ }^{*}$ Created audio snippets for permanent exhibit using Sony editing software.

*Used Past Perfect to create records for many oral history holdings.

University of Louisville Cressman Gallery- 8/2009 - 6/2010, Gallery assistant

*Assisted in hanging, packing, and shipping artwork for bi-monthly exhibits.

Solid Light- 1/2010 - 5/2010, Intern as Researcher 


\section{Curated Exhibitions}

The Brutal Aesthetic- Boxing photographs of John Ranard

Muhammad Ali Center, 9/2011 - 11/2011

Once Upon a Holiday- Paintings of holidays around the world

Muhammad Ali Center, 11/2011 - 1/2012

Musicircus- An event inspired by John Cage

Hite Art Institute Galleries, April 7, 2012. One day only.

Skills $\quad{ }^{*}$ Computer

Past Perfect 4.0E4 and previous versions

Archivist Toolkit

Photoshop

MS Office

Proficient in Windows and Mac platforms

*Proficient with tools

*Detail-oriented

*Multi-tasking

Education BA-Photography and Video, University of Kentucky

MA-Critical and Curatorial Studies, and Certificate in Public History,

December 2012, University of Louisville.

Campbell Center for Historic Preservation, Care and Preservation of Photographs I \& II. 